\title{
More than a Feeling: Personality and Congressional Behavior*
}

\author{
Adam J. Ramey ${ }^{\dagger}$ \\ Jonathan D. Klingler \\ Gary E. Hollibaugh, Jr. $\$$
}

August 22, 2014

\begin{abstract}
Political scientists have long considered the primacy of ideology, party affiliation, and constituency preferences in determining how members of the U.S. Congress make decisions. At the same time, psychologists have held that individuals' ingrained personality traits play a central role in individual decision-making. In this paper, we seek to bridge these literatures by offering a rational-choice based characterization of how personality informs legislator decisionmaking, independently of policy preferences, and demonstrating empirical evidence for this approach. We use floor speeches in the Congressional Record in conjunction with machine learning techniques to generate legislator personality estimates across the Big Five personality dimensions from 1996-2013. These results in hand, we study how legislators' personality traits affect their behavior in Congress, focusing on the key tactic of bill sponsorship. Our results show that personality has a strong relationship with legislator behavior-even after controlling for legislator ideology.
\end{abstract}

${ }^{*}$ Authors are listed in reverse alphabetical order. Support through ANR - Labex IAST is gratefully acknowledged.

${ }^{\dagger}$ Corresponding author. Assistant Professor of Politics, New York University Abu Dhabi, PO Box 129188, Abu Dhabi, United Arab Emirates. Email: adam.ramey@nyu.edu

¥Postdoctoral Fellow, Institute for Advanced Study in Toulouse, 21 alleé de Brienne, Toulouse 31000, France. Email: jonathan.klingler@iast.fr

\$Assistant Professor, Department of Political Science, University of Notre Dame, Notre Dame, IN 46556. Email: gholliba@nd.edu 


\section{Introduction}

On October 16th, 2013, the United States Senate voted 83-16 in favor of a bipartisan agreement ending a 16 day government shutdown that resulted in part from an impasse between Democrats and Republicans over the continued implementation of the Patient Protection and Affordable Care Act, alternatively referred to as Obamacare. Republican Senators Pat Roberts and Jerry Moran of Kansas entered the chamber with very nearly identical ideological positions, as measured by their DW-NOMINATE ideological scores. ${ }^{1}$ Prior to the shutdown, both had argued in favor of having a "discussion about not funding the government in hopes of getting a repeal of Obamacare." ${ }^{2}$

However, just over two weeks into the shutdown, the two senators from Kansas diverged with respect to their tactics and the decision to continue to use the shutdown to force policy concessions. Senator Roberts, a vocal advocate of the decision to insist on a funding bill that eliminated all funding for the health care law, voted against the measure, justifying his vote by citing "catastrophic problems with Obamacare" and claiming that there will be "no way out for Kansas families because the problems are so large and systemic.”3 However, Senator Moran, while ideologically similar to his fellow Kansan, voted in favor of the measure. Initially viewing the shutdown as a vehicle with which the Republican Party could extract policy concessions and force a defunding of the health care law, he soon changed his mind, deciding that there was "no way [he] could see the President signing a piece of legislation that undoes his signature piece of legislation" and refusing to leave his constituents with "a lot of difficult things happening" because of "a government that doesn't function." $\mathrm{He}$ voted for cloture to allow the agreement ending

\footnotetext{
${ }^{1}$ Both senators were given a DW-NOMINATE score of 0.440 , placing them around the ideological middle of the Republican caucus.

${ }^{2}$ Wilson, Ryan D. 2013. "Moran: Obamacare won't be repealed," Clay Center Dispatch, December 2, 2013, http://www.ccenterdispatch.com/news/article_8e8bf18a-5b97-11e3-a819-001a4bcf6878.html.

${ }^{3}$ The Topeka Capital-Journal. 2013. "Roberts, Moran split on raising debt ceiling; Jenkins lone yes vote in House," October 16, 2013, http://cjonline.com/news/2013-10-16/ roberts-moran-split-raising-debt-ceiling-jenkins-lone-yes-vote-house.

${ }^{4}$ Wilson, “Moran: Obamacare won't be repealed."
} 
the shutdown to proceed to a full Senate vote, as well as for the final bill itself.

Given the ideological similarity of Senators Roberts and Moran, as well as the high-profile nature of the government shutdown, their divergent votes on the bill to end the shutdown come as a bit of a surprise. Indeed, the workhorse spatial model of voting explicitly assumes that legislators select actions purely on the basis of the proximity of legislators' ideal points to the positions of the alternatives under consideration. This approach assumes the bills and procedures on which legislators vote implement a policy with certainty, that legislators are indifferent between different tactics which could achieve the same policy outcome, and that the eventual policy outcome is known a priori to all legislators. This simplification-while useful for modeling purposes and mathematical tractability-is inherently flawed, as individuals who share common policy objectives frequently debate amongst themselves over which tactics and procedures are preferred, and which are most likely to achieve shared goals.

Here, we argue that legislators do not act solely upon policy positions per se, but also on intermediary tactical actions that bridge individual policy preferences and legislative outcomes. ${ }^{5}$ Individuals are uncertain as to which tactical actions are most likely to achieve their desired ends, and they also derive varying amounts of utility from how policy is produced. ${ }^{6}$ In the Roberts/Moran example, both Senators were similarly conservative and both wanted to reduce governmental borrowing and spending. However, they disagreed over whether the tactical mechanism-the shutdown-was the best and most appropriate means by which they can achieve their shared goal. Each Senator used his own preferences/beliefs about the translation from tactics to policy and came to a different decision, with one voting to continue the shutdown and the other voting to end it. Thus, an essential prerequisite to understanding legislative behavior is to characterize and estimate the beliefs of legislators over divergent tactics. But how?

\footnotetext{
${ }^{5}$ That is, the process by which a particular tactical action transforms policy preferences into legislative outcomes is inherently noisy, and legislators can prefer one tactic to another in pursuing the same outcome.

${ }^{6}$ For legislators, like children being scolded by their mothers, it is not simply what one says that matters, but how it is said.
} 
We argue that, in line with a growing literature in experimental economics and psychology, preferences and beliefs of individuals over risk, time, altruism, and their own efficacy play extremely important roles in the processes rational legislators use to choose optimal procedural actions. These key preferences and beliefs offer a challenge to researchers as they may be difficult to measure effectively. However, personality psychology, experimental economics, and computer science are quickly developing new and promising methods to measure these parameters. Contemporary work in these fields has connected the canonical Five-Factor Model (i.e., Extraversion, Agreeableness, Openness [to Experience], Conscientiousness, and Emotional Stability) of personality to concepts more provincial to economics (e.g., risk, time, altruism, and efficacy), thereby enabling scholars to use the Big Five personality traits as an apt summary of preferences over tactics. Further, while traditional approaches for studying personality have required either laboratory experiments or surveys to measure personality, recent advances in text analysis and machine learning have enabled researchers to measure the Big Five traits using indirect textual methods, thereby creating new possibilities for more historical analyses of personality.

This paper contributes to this diverse literature and applies it, for the first time, to the study of legislative behavior. First, we review the literature and show how each of the Big Five traits can be connected to non-ideological preferences and beliefs identified by experimental economists, demonstrating that parameters revealed by personality may plausibly influence the decisions made by rational legislators. Then, we draw on advances in machine learning to estimate the Big Five DYNAmic PERsonality (DYNAPER) scores of every member of the U.S. Congress from 1996-2012. Putting our posited linkages between personality and non-ideological preferences to the test, we then use our measures to explain variance in bill sponsorship behavior that cannot be explained by policy preferences alone. We focus our analysis on the key tactic of bill sponsorship, but we also examine other aspects of the legislative process and highlight the influence of parameters revealed by personality. Following this, we discuss potential avenues for future research. 


\section{Existing Literature}

For decades, researchers have argued that candidates are judged—at least in part-on the basis of attributes unrelated to the policies they espouse on the campaign trail (Enelow \& Hinich 1982, Holian \& Prysby 2014, Stokes 1963). Many, but not all, of the non-policy attributes on which candidates are judged are effectively beyond their immediate control, such as personal history. Distinctions between these ingrained characteristics and other, more malleable, policy attributes have been made since the early days of spatial voting models. For example, Stokes (1963) argued that candidates have both position and valence characteristics; Enelow \& Hinich (1982) further discretized valence attributes, breaking them down into valence attributes-immutable attributes on which all voters hold the same evaluation-and ascriptive attributes-immutable attributes on which the evaluations of voters differ-with one of the primary distinctions between the types of attributes being that candidates can choose position attributes, while valence and ascriptive attributes cannot be selected.

This wide array of possible attributes means that voters who have preferences over implemented policies not only need to evaluate candidates on the basis of their policy preferences, but also on their (perceived) ability to implement complex legislation in a manner that produces the preferred policy outcome. A large body of work over the past thirty years has demonstrated that leadership qualities that determine the effectiveness of policy implementation (leadership, competence, open-mindedness)-as well as the manner in which policy outcomes are pursued (empathy, aversion to war)-do matter to voters (Funk 1996, Funk 1997, Funk 1999, Kinder et al. 1980, Mondak 1995). ${ }^{7}$

In contrast with the conceptual smorgasbord of trait names and definitions offered by this

\footnotetext{
${ }^{7}$ Moreover, it is not just voters who care about the competence, integrity, effort, and effectiveness of officeholders. When choosing those appointees ultimately responsible for policy implementation, executives have long weighed competence-and other nonpolicy factors-as important considerations necessary to effective policymaking (Aberbach \& Rockman 2000, Gailmard \& Patty 2007, Hollibaugh 2014, Hollibaugh, Horton \& Lewis 2014, Huber \& McCarty 2004, Lewis 2008, Lewis 2009, Moe 1985, Nathan 1983).
} 
literature, psychologists have somewhat coalesced around the common language of the Big Five personality traits-alternatively referred to as the Five-Factor Model-to describe important behavior (Gerber et al. 2011). Over the past half-century, these five dimensions of personality have consistently explained the lion's share of the variance in personality differences in repeated studies, the results of which have been quite robust across multiple cultures, contexts, measures and samples (Costa \& McCrae 1992, Goldberg 1990, Norman 1963, John, Robinson \& Pervin 2010). These traits-Extraversion, Agreeableness, Openness [to Experience], Conscientiousness, and Emotional Stability-have been found to be substantively distinct from one another, though some cross-dimensional correlations have been discovered (Aluja, García \& García 2002). Moreover, there has been significant work done by psychologists to clarify our collective understanding of what each of the traits capture about personality and to identify the words and concepts most closely related to each trait (Goldberg 1992, Saucier 1994). While personality psychologists do differ on precisely what defines each dimension, there is substantial agreement on the broad nature of the dimensions and that they encompass most (though certainly not all) of what influences personality at the top level.

To this effect, personality psychologists have recently begun their own efforts to argue that risk and time preferences from decision theory are rooted in part in biologically-derived personality traits (Anderson et al. 2011). Building on these and other works, an ambitious research agenda is being pursued with the goal of fully incorporating personality traits into the rational choice paradigm, developing a general model in which individuals have comparative advantages in completing tasks under uncertainty (Almlund et al. 2011, Ferguson, Heckman \& Corr 2011). Two key elements of the model involve the requirement that individuals take actions, which are "styles of behavior that affect how tasks are accomplished" and that situations (which include imposed incentive structures) influence behavior (36). The parameters that persist across tasks and situations are considered traits, including-but not limited to-the endowment of effort, ability, preferences, prices of action, rewards to productivity, outcomes of purchase decisions, and the 
degree to which individuals are informed about these parameters. Additionally, experimental research is ongoing in an effort to connect different measures of particular personality traits to hypothesized parameters (Almlund et al. 2011). ${ }^{8}$ As experimental economists work to link each trait with different belief and preference parameters (or families of such parameters, the traits are found to have substantively different effects on behavior in rational individuals.

Here, we circle back to the candidate evaluation literature, which implicitly and explicitly acknowledged that the nature of policy implementation has an impact on the resulting outcome, justifying concern by voters over leadership traits. To wit, a growing body of political science research has found links between Openness and liberalism and between Conscientiousness and conservatism, as well as other relationships between the Big Five and political attitudes (see Gerber et al. (2011) for a review). The Big Five personality traits of politicians capture differences in how they evaluate the actions they must undertake in order to accomplish their preferred policies. Simultaneously, based on surveys of legislators in which they placed themselves unusually highly on each of the five traits, legislators may believe voters evaluate the actions of politicians in terms of how well they reflect valence attributes of openness to new ideas, a strong work ethic, optimism, selflessness, and level-headedness, reflected in the Big Five (Dietrich et al. 2012). While politicians may have incentives to act as if they hold these valence leadership attributes, misrepresentation is potentially costly and we should still see variation in the behavior of imperfectly informed yet rational politicians as they weigh the benefits of misrepresenting their attributes against their own preferences and information limitations. Thus, we argue that the behavior of legislators is substantially influenced by how they view risk and delay, altruism, and their own

\footnotetext{
${ }^{8} \mathrm{~A}$ great deal of work remains to be done in this area, and it is a major element of of the proposed research agenda in (Ferguson, Heckman \& Corr 2011). It is important to note that the Big Five personality traits are necessarily broad concepts as they were designed to capture as much variance as possible in general human behavior. These traits have multiple facets, and within the Almlund et al. (2011) model, multiple parameters could have similar but slightly different effects on the prevalence of particular actions. Thus, measures of the Big Five by necessity conflate multiple parameters which appear to be correlated but likely vary across individuals. In the future more nuanced measures are needed, but we view our utilization of the Big Five as proxy measures for economic parameters to be a conservative first step in measuring the key economic parameters of legislators.
} 
efficacy. Personality traits serve not only to identify these particular parameters as important influences on the evaluation of tactics and actions in the pursuit of goals, but also serve as measures of these parameters.

\title{
The Big Five and Economic Parameters
}

\author{
[Table 1 about here.]
}

Our goal in this paper is to demonstrate the broad relevance of personality measures in examining tactical behavior in Congress. We draw from the experimental economics literature to obtain parameters correlated with the Big Five that are important to political decision-making. As we will discuss later in the paper, we believe bill sponsorship is an ideal first tactic to examine, both because of its utility to policy-motivated legislators, and because of the accessibility of data on the subject. Thus, we will use the parameters correlated with the Big Five personality measures to hypothesize about how each of the Big Five traits should themselves be associated with elements of bill sponsorship. The project to uncover associations between personality traits and underlying preferences is still in its early stages, and there remains considerable disagreement over the strength and robustness of these associations. We leave the goal of empirically identifying the precise nature of these traits for other work, though we believe this paper will contribute to that effort.

\section{Openness to Experience}

The tendency to be open to new aesthetic, cultural, or intellectual experiences. (VandenBos 2007)

A short inventory of 40 adjectives, or mini-markers, is commonly used in assessments to describe the Big Five (and their inversions), and the eight mini-markers for Openness to Experience 
are creative, imaginative, philosophical, intellectual, complex, deep, uncreative, and unintellectual (Saucier 1994). Openness to Experience is described in the literature as a preference for novelty, sensitivity to transcendent experiences, and intellectual curiosity (Costa \& McCrae 1992, Furnham, Monsen \& Ahmetoglu 2009, Saroglou 2002). This trait is notoriously difficult to pin down, and there has been considerable debate over whether it is a measure of intelligence or curiosity (McCrae 1994).

A 2010 paper in which respondents were repeatedly asked to choose between a varying safe amount of money and a lottery found that individuals scoring higher on Openness to Experience were more likely to choose the lottery even at higher values of the safe amount of money, suggesting Openness to Experience is associated with greater risk preference (Dohmen et al. 2010). The link between Openness to Experience and lower risk aversion is also suggested by (Almlund et al. 2011) when they quote the definition provided by Zuckerman et al. (1964) for impulsive sensation seeking, "the tendency to seek novel, varied, complex, and intense sensations and experiences and the willingness to take risks for such experiences" (99). Additionally, the characterization of Openness to Experience as a measure of an individual's preference for risk (and accordingly, tolerance for loss) is consistent with findings that the trait is associated with highpayoff-but potentially destabilizing-behaviors such as engagement with non-traditional spirituality and deep learning (Furnham, Monsen \& Ahmetoglu 2009, Saroglou 2002).

\section{Conscientiousness}

The tendency to be organized, responsible, and hardworking. (VandenBos 2007)

The eight mini-markers for Conscientiousness are organized, efficient, systematic, practical, disorganized, sloppy, inefficient, and careless (Saucier 1994). This trait was one of the first to be identified in personality psychology, and has been described by (Webb 1915) as "persistence of motives" and "consistency of action resulting from deliberate volition, or will" in early work 
on character (60). The theme of willpower and self-discipline emerges frequently in discussions about Conscientiousness, as people with high scores on these measures tend to be more driven, goal-oriented and uptight (Ozer \& Benet-Martinez 2006).

Experimental results from an economic discounting study found that higher scores on Conscientiousness were associated with a lower discounting of future payoffs (Daly, Harmon \& Delaney 2009). Though Daly, Harmon \& Delaney (2009) state that "conscientiousness is particularly implicated in the ability to make sacrifices now for rewards later," their study also suggested that low Extraversion was also linked with low discounting (60). In another study, Conscientiousness was found to have a weaker relationship with time preferences (Dohmen et al. 2010). Though the early experimental research on time preferences has provided mixed results, modeling of willpower as an individual's time preferences does appear to produce predictions consistent with variations in the behavior of individuals depending on their levels of Conscientiousness.

\section{Extraversion}

An orientation of one's interests and energies toward the outer world of people and things rather than the inner world of subjective experience; characterized by positive affect and sociability. (VandenBos 2007)

The eight mini-markers for Extraversion are talkative, extraverted, bold, energetic, shy, quiet, bashful, and withdrawn (Saucier 1994). Extraversion, like Conscientiousness, has a long history of study among psychologists, and early researchers described the trait as consisting of both sociability and impulsiveness (Eysenck 1967, Eysenck 1991). Personality psychologists describe Extraversion as the tendency to experience positive emotions, and includes a variety of characteristics like gregariousness, assertiveness, energy, and activity that appear linked with perceptions of high expected rewards (Costa \& McCrae 1992, DeYoung et al. 2010, John, Robinson \& Pervin 2010). Extraverted individuals have been found to be more likely to participate in election 
activities (Gerber et al. 2011, Mondak et al. 2010).

Attempts to link Extraversion with specific preferences have resulted in a number of fairly scattered findings. Extraversion has been found to be linked with the region of the brain tasked with coding the reward values of stimuli (DeYoung et al. 2010). Additionally, and as previously mentioned, Extraversion is also associated with increased impulsivity through increased discounting of future payoffs (Daly, Harmon \& Delaney 2009). Experimental evidence also suggests that Extraversion is linked with high and stable expectations of success (i.e., achieving an outcome with the highest utility) in noncontingent trials (Pearce-McCall \& Newman 1986). Notably, a number of experimental studies have failed to find an association between Extraversion and risk preference per se, adding support to the argument that it is linked with assessment of outcome payoffs rather than aversion to risk, regret, or loss (Almlund et al. 2011).

\section{Agreeableness}

\section{The tendency to act in a cooperative, unselfish manner. (VandenBos 2007)}

The eight mini-markers for Agreeableness are sympathetic, warm, kind, cooperative, cold, unsympathetic, rude, and harsh (Saucier 1994). The trait is described as linked with being likable,

pleasant and harmonious in relationships with others (Graziano \& Tobin 1997), altruism (Almlund et al. 2011, DeYoung et al. 2010), and a tendency to trust others (Almlund et al. 2011, John, Robinson \& Pervin 2010). While the positive nature of this trait may lead to the impression individuals may seek to misrepresent themselves on this dimension to send socially desirable signals, there is evidence that the trait's expression is robust to self-favoring biases among the general public (Graziano \& Tobin 2002).

A 2008 survey found that Agreeableness was strongly linked to self-reported low negative reciprocity; after Conscientiousness, it had the strongest positive relationship with positive reciprocity (Dohmen et al. 2008). Additionally, there appears to be some relationship between Agree- 
ableness and helping others who are generous while being reluctant to punish others if wronged. Somewhat stronger evidence from a 2008 trust game experiment found that Agreeableness was strongly associated with the amount sent, but when a self-reported trust measure was included, the relationship between the amount sent and Agreeableness evaporated (Evans \& Revelle 2008). This suggests Agreeableness measures may be noisily capturing an underlying preference for trusting others. Furthermore, no other trait in the Big Five was associated with the amount sent in the trust game.

Though much more research is needed, these early results from survey and experimental research suggest that Agreeableness is linked to trust, and willingness to help-as well as a reluctance to hurt-others, even when punishing others may promote cooperation. If Agreeableness were associated with a simple cooperation preference, there should be a positive relationship with negative reciprocity as it helps maintain cooperation. Instead, Agreeableness is negatively associated with negative reciprocity (Dohmen et al. 2008). This suggests, along with the positive relationship with trust and positive reciprocity, that Agreeableness is associated with social preferences for the welfare of others, be they difference-aversion, social-welfare preferences, or something else (Charness \& Rabin. 2002).

\section{Emotional Stability}

Neuroticism is a chronic level of emotional instability and proneness to psychological distress. (VandenBos 2007)

Finally, the eight mini-markers for Emotional Stability (referred to in the inverse by many as Neuroticism) are moody, jealous, temperamental, envious, touchy, fretful, unenvious, and relaxed (Saucier 1994). The trait of Emotional Stability is associated with low levels of anxiety, depression, impulsiveness and vulnerability to stress (Almlund et al. 2011). Furthermore, related traits include internal locus of control, low irritability and a sense of low vulnerability to external con- 
ditions (John, Robinson \& Pervin 2010). Personality psychologists suggest that emotionally stable individuals are both less reactive to stress and focus less on negative outcomes, in opposition to Extraverts who tend to exhibit exaggerated beliefs in positive outcomes (Larsen \& Ketelaar 1989).

Emotional Stability has been found to be related to risk aversion in a number of experiments (Almlund et al. 2011, Anderson et al. 2011). It is worth noting that the relationship between a number of personality traits and behavior appear to be transmitted through various parts of individual relationships to risk. Openness to Experience appears to reflect risk preference and Extraversion the skew of expected payoff distributions (Almlund et al. 2011, John, Robinson \& Pervin 2010). Low Emotional Stability appears to represent the opposite of both these qualities, and has found to be negatively associated with both empirically (Anderson et al. 2011, Borghans et al. 2009, Judge et al. 2002). Individuals with low Emotional Stability have a low internal locus of control, which distinguishes between the belief that internal choices and will control outcomes in one's life in relation to external influences such as luck, fate or powerful others (Judge et al. 2002, Rotter 1990).

\section{Measuring Personality: From Speeches to Scores}

\section{Limitations of Existing Approaches for Elected Officials}

Despite the tremendous advances in the measurement of the Big Five, most political science applications using these metrics involve surveys of voters (Caprara, Barbaranelli \& Zimbardo 2002, Gerber et al. 2011). While enlightening, these studies tell us precious little (if anything) about the personality traits of elected officials. An obvious, simple solution to this deficit would be to survey legislators ourselves. Unfortunately, such an approach would likely be impractical for a number of reasons. First, survey or lab-based instruments are only implementable in the present, thus precluding us from being able to look at the dynamics of personality over time. Second, even if we restrict ourselves to contemporary Congresses, there is little reason to believe that most leg- 
islators would be willing to take such inventories. Even if responses were possible to obtain, such estimates would be subject to selection bias and strategic responses.

We are certainly not the first scholars to recognize this limitation. This is almost certainly to blame for the lack of virtually any systematic study of legislator personality traits. To our knowledge, only one study-and a recent one at that-has attempted to apply traditional surveybased inventories with legislators (Dietrich et al. 2012). ${ }^{9}$ The study was focused on state legislators from only three states: Maine, Arizona, and Connecticut. In line with our concerns above, response rates were low-ranging from $17 \%$ to $26 \%$ of legislators.

Perhaps even more troubling, the responses of legislators to the Big Five questions appear to display high degrees of desirability bias. On each of the dimensions, in excess of $77 \%$ and in many cases, more than $90 \%$ ) of legislators responded in a way to convey the "positive" side of each dimension. Indeed, for the cases of Agreeableness, Openness, and Emotional Stability, the percentage of legislators identifying as non-agreeable, closed, and/or neurotic are in the low single-digits. This distribution of personality trait scores may certainly reflect reality. However, such overwhelming positivity bias suggests that survey instruments, even when possible to conduct, will lead to low response rates and uninformative personality profile estimates, due to lack of variation.

\section{Using Speech to Measure Personality Traits}

Therefore, we posit that the key to studying the role of each dimension of the Big Five in legislator behavior lies in measuring legislator personality in a consistent, reliable manner that does not rely on direct surveys. To solve this puzzle, we draw on a very recent literature in machine learning that seeks to connect personality traits with both written and spoken word (Golbeck et al. 2011, Li \& Chignell 2010, Mairesse et al. 2007, Mairesse \& Walker 2008, Mairesse \& Walker 2010, Schuller et al. 2013). This literature uses traditional psychometric personality inventories

\footnotetext{
${ }^{9}$ Though see Silvester, Wyatt \& Randall (2014).
} 
in conjunction with written texts, Tweets, and auditory transcriptions to train predictive models for personality. Once the known personalities of a subset of authors are calibrated with their linguistic usage, "virgin texts" can be assessed for personality content, even in the absence of the true personalities as measured by traditional inventories.

In one of the most cited papers in this burgeoning literature, Mairesse et al. (2007) develop one of the most widely-applicable methods for translating text in to personality estimates. Using Pennebaker \& King (1999)'s corpus of over 1.9 million words from laboratory experiments on word usage, Mairesse et al. (2007) train a series of machine learning models to predict personality traits from linguistic usage. Words are not treated as independent entities, but are first preprocessed according to one of more than 70 categories developed by Pennebaker, Francis \& Booth (2001) as the Linguistic Inventory and Word Count (LIWC). This is crucial, as it allows for generalizability to virgin texts that cover differing topics than their test sample. The LIWC's classification scheme searches for a variety of linguistic features in a text, ranging from the number of first person pronouns to the number of six letter words to swear words and more. After preprocessing the Pennebaker \& King (1999) corpus through the LIWC, Mairesse et al. (2007) train a number of standard machine learning algorithms on a random test sample from the corpus. Across the various models, they find that Support Vector Machines for Regression (SMOreg) has the best performance for recovering the true personalities of the laboratory respondents in non-auditory trials.

Since the Mairesse et al. (2007) approach does not rely on specific vocabulary and instead relies on word categorization via the LIWC, any virgin texts may be fed to the trained models to get personality estimates. Applying this approach to Congress requires a set of legislator texts over time to draw upon. To that end, arguably the most systematic data available for legislators over time are their speeches on the floors of the House and Senate. These speeches are found in the Congressional Record and are publicly available from the House and Senate clerk websites. A few concerns are obvious with using this data. Just as with using survey-based estimates, it is possible 
that legislators use their floor speeches to strategically convey either their policy preferences, the preferences of their constituents, or (remote, but possibly) a personality or leadership profile to their constituency audience. The first two concerns do not seem to be such a problem, as Factor Analytic and Correspondence Analysis scalings of these texts do not seem to discriminate between legislators in ideological or partisan manners. ${ }^{10}$ As for the third concern, this is really only a problem if legislators are trying to convey a profile that is "fake." For example, a legislator may want his or her constituents to think he or she is extraverted when he or she is actually introverted. While this is potentially damning, this effect would simply attenuate our results in a direction counter to our expectations, if it existed. Furthermore, if some legislators were speaking sincerely and others strategically, this would result in further attenuation, whereby our personality estimates would have no predictive power.

These concerns aside, we apply Mairesse et al. (2007)'s SMOreg model to the corpus of every legislative speech by every sitting member of the House of Representatives and the Senate from 1996-2012 (104th-112th Congresses). The data for this exercise were culled from the Sunlight Foundation's Capitol Words API. ${ }^{11}$ Using these data, the procedure for implementing the Mairesse et al. (2007) method is as follows:

1. For each set of speeches given by a given legislator in a fixed time span (in our case, by Congress), process the raw text file through the LIWC to get counts of word usage across all LIWC categories.

2. Once all legislators' speeches have been processed for the given span, feed the directory of texts through the Mairesse et al. (2007) pre-trained models in corpus mode. This mode normalizes the set of texts to downweight word categories that there not present in Con-

\footnotetext{
${ }^{10}$ In the attached appendix, we show that our measures of the Big Five, while correlating with ideology estimates of members of Congress, explain only a small fraction of the variance in the data. This suggests that personality, while related to ideology, is not an equivalent construct and that our estimates have substantive meaning independent of it.

${ }^{11}$ See http://api . capitolwords.org/ for details.
} 
gressional speeches. ${ }^{12}$

3. The output from Step 2 (Big Five estimates for each legislator) is saved and the process is repeated for as many Congresses as there are available.

4. Since the nature of political discourse correlates with a shifting agenda and legislative priorities over time, we apply Groseclose, Levitt \& Snyder (1999)'s scale-and-stretch adjustment to the raw scores, thus obtaining scores comparable over time. Specifically, let $\theta_{i t}^{d}$ be legislator $i$ 's personality estimate on Big Five dimension $d$ in Congress $t$. Following Groseclose, Levitt \& Snyder (1999),

$$
\theta_{i t}^{d}=a_{t}+b_{t} \theta_{i}^{d}+\varepsilon_{i t}^{d}
$$

where $\left(a_{t}, b_{t}\right)$ are the yearly inflation factors, $\theta_{i}^{d}$ is $i$ 's over-life average personality on dimension $d$, and $\varepsilon_{i t}^{d}$ is a Normally-distributed error term. Once we estimate $\left(a_{t}, b_{t}\right)$, we adjust the yearly scores accordingly, i.e.,

$$
\frac{\theta_{i t}^{d}-\hat{a}_{t}}{\hat{b}_{t}} .
$$

For identification, we set $a_{104}=0$ and $b_{104}=1$, making the first Congress in our dataset the baseline.

Henceforth, we refer to these time-adjusted estimates as DYNAmic PERsonality (DYNAPER) scores. ${ }^{13}$ It is crucial to note that we are agnostic as to whether (a) DYNAPER scores are measures of "true" legislator personality and (b) whether true personalities are changing over time. Like with ideal-point estimates based on roll calls, we simply consider these estimates as a revealed and potentially strategic preference. Given this, a legislator could change their revealed personalities

\footnotetext{
${ }^{12}$ JAVA code for the approach is found here: http://people.csail.mit.edu/francois/research/ personality/recognizer.html.

${ }^{13}$ Upon publication, the scores and all auxiliary data will be released on the corresponding author's website.
} 
from year-to-year irrespective of any true, latent changes in their underlying personalities. The dynamics could reflect changes in underlying preferences, but we remain agnostic nevertheless. ${ }^{14}$

\section{A Note on Strategy}

We acknowledge the possibility that legislators may have potentially strong incentives to misrepresent their "true" personality traits in order to adopt false personas. In this case, their behavior and language would be affected to portray the desired false traits rather than the traits they hold with conviction. While we acknowledge this concern as a serious issue, based on the evidence currently available, we do not believe that it is a serious impediment to the measurement of legislators' beliefs and preferences, exhibited through the Big Five personality traits.

Indeed, a common objection to the standard NEO-PI-R personality inventory introduced by Costa \& McCrae (1992) is that the "desired" trait or answer is transparent to respondents. In our experience, critics of the inventory argue that the average respondent would certainly prefer to think of themselves as extraverted rather than introverted, emotionally stable rather than neurotic, agreeable rather than selfish, conscientious rather than lazy, and open to experience rather than insular. ${ }^{15}$ This concern appears to gain some support in data recently released from administering personality inventory questions to state legislators (Dietrich et al. 2012). The Big Five personality trait questionnaires show that the responding legislators' responses are substantially skewed toward these "favorable" personality trait values, suggesting that personality traits serve as valence characteristics.

Legislators may very well consciously adopt speech patterns in order to signal these valence personality characteristics. There are likely a large variety of verbal cues which both indicate per-

\footnotetext{
${ }^{14}$ Traditionally, psychologists considered personality fixed, but recent studies have claimed there are dynamic changes over the lifecycle. This debate is fairly complex and controversial. For this reason, we take a neutral stance and account for dynamics mostly out of concerns of strategic behavior of legislators.

${ }^{15}$ While this may seem to bias the results, there is substantial variation in sample responses that allow the measure to retain meaning. This is likely due to efforts to maintain credibility, as when candidates try to pivot to the center following a primary campaign and cannot with credibility adopt the position of the median voter. If acting against one's preferences and belief structures is costly, it would be difficult to credibly present a false personality
} 
sonality types to legislators and voters, and which are known to all and be voluntarily suppressed or performed insincerely. However, we also assume that there exists some subset of these verbal cues tied to personality, which are not known to legislators, but which may be captured by the personality recognizer algorithm described above.

We suppose that legislators also have unconscious verbal cues that signal personality and that the algorithm can read these cues. In that case, it is in the interests of legislators to misrepresent their personality traits by appearing to hold personality trait values which are as favorable as possible throughout their public speech. While all the known cues should be utilized by legislators to develop valence trait values, the unknown subset of cues should exhibit substantial variation as legislators are simply unaware of their link with personality type. Combining these known and unknown subsets of speech elements should result in measures that appear skewed toward the valence characteristics, but with substantial variation reflecting the true variation in the underlying trait values.

\section{Bill Sponsorship and the Big Five}

We introduced this paper by describing legislative tactics as a means of implementing policy, and argued that personality traits help us understand why legislators view some tactics to be the best means by which they can achieve their policy goals. In our empirical analysis, we seek to initially evaluate this approach by selecting a important tactic which is used by legislators to a varying degree, and mostly helps them achieve policy goals. We will then list and test hypotheses regarding how personality should be expected to be associated with this tactic.

Voting may appear to be the ideal tactic to examine at first given the amount of data available through roll calls and the centrality of these votes to the responsibilities of legislators. We do consider bills to be implementation actions and votes between them to be decisions that legislators make about which actions are best. Ideally, we would be able to estimate the ideological position 
as well as the riskiness of the bill, the delay in providing a payoff, etc. However, we currently lack broadly applicable methods for measuring these qualities, making votes between bills and status quos unsuitable for our purpose of investigating the usefulness of personality trait measures in predicting congressional decisions over tactics ${ }^{16}$.

As voting is not suitable, we believe that bill sponsorship provides an excellent second-best tactic for examination at this stage. Proposing legislation is the essence of legislative policy leadership, and while votes only allow members to potentially decide between a status quo and the proposal of another member, if a member's bill comes to the floor for a vote, a member has the opportunity to obtain the most favorable policy they believe is possible in a salient policy area. For policy-motivated members, sponsoring and cosponsoring bills will likely provide the most utility gain for the effort expended. ${ }^{17}$ In particular, we focus on three aspects of the bill sponsorship process-the initial introduction of bills, the symbolic/substantive nature of the sponsored bills, and the decision to cosponsor, with an emphasis on bipartisan cosponsorship.

\section{Empirical Analysis}

\section{Introducing Bills}

While ideology and whether or not a member is part of the majority will likely have an effect on how many bills a legislator will put on the docket, we know precious little else as to what intrinsic qualities may motivate a legislator to propose bills. However, in terms of personality traits, we believe Extraversion is important to understanding this phenomenon. Legislators who have a high degree of Extraversion, and thus a higher expected payoff when payoffs are relatively unknown (and the payoffs of inaction-and therefore maintaining the status quo-are generally

\footnotetext{
${ }^{16}$ It is our hope that such data will be available in the future, perhaps through the use of text analysis, expert surveys, or some combination of the two.

${ }^{17}$ Of course, this assumes there are no other members with identical ideal points who may allow free-riding to occur, so we have to assume ideology has an interactive effect in this area, as more moderate members will find it easier to free-ride off of others and not face the same benefits to introducing legislation.
} 
better known than those resulting from some deliberate course of action), should behave in distinctive ways when introducing legislation. More Extraverted legislators will believe that the actions they take are more likely to be worth the effort when the costs of effort are known and the potential rewards are relatively high. Thus they will tend to have a higher expected utility for taking action toward their policy preferences in comparison to doing nothing. Accordingly, assuming that the process of sponsoring a bill is more or less the same action over time, but the chances of success are different for every bill, more Extraverted legislators' inflated expected utilities for introducing these bills will lead them to sponsor more bills than they would if they were less Extraverted. ${ }^{18}$ This yields the following hypothesis:

Hypothesis 1 More Extraverted legislators should sponsor more bills than less Extraverted legislators.

However, we also expect Emotional Stability to be working at cross-purposes. The previouslydiscussed association between this trait and a more internal locus of control would suggest that individuals with low Emotional Stability scores are more likely to believe that external influences determine the outcomes in their life over internal influences such as choice and effort. Any object which requires costly expenditure of effort to obtain would be pursued less often as an individual's locus of control becomes more external. This is because the weakening of the connection between effort and gains effectively reduces the expected utility of effort and diminishes the likelihood that the exchange of certain effort for perceived uncertain gains is unprofitable. Introducing legislation and leading efforts to push a bill through the legislative process demands more effort than other tactics which could be used, such as signaling support through cosponsorship, so we should expect the following:

\footnotetext{
${ }^{18}$ This is equivalent to a two-stage decision in which a legislator may choose to sponsor or not to sponsor a bill, and, following the decision to sponsor, a particular bill is chosen. If the costs of sponsorship are incurred in the first stage and the payoff from a particular measure are assessed in a separate stage, the costs of sponsorship may be well-known from repeated samples while the payoffs for bills remain inflated by the skewed prior of an extraverted legislator.
} 
Hypothesis 2 More Emotionally Stable legislators should sponsor more bills than less Emotionally Stable legislators.

We also expect Conscientiousness to play a role, as we readily note that legislators who are conscientious want to work hard, invest now for payoffs in the future, and effectively perform the job that they were sent to Washington to do. Choosing to introduce legislation rather than support it through other methods such as signing on as an additional cosponsor or mobilizing support through the media is a significant responsibility which is held until the bill becomes law (or expires), taking energy and effort which could otherwise have been expended in the pursuit of quick wins in the current news cycle but instead go toward longer term potential policy gains. Instead, Conscientious members should be more likely to introduce bills overall. This yields the following hypothesis:

Hypothesis 3 More Conscientious legislators should sponsor more bills than less Conscientious legislators.

Table 2 shows the results from a series of Poisson regressions of the number of bills introduced by each member per session of Congress, controlling for members' ideological extremityoperationalized as the absolute value of the DW-NOMINATE scores-and DYNAPER scores. Models with and without random effects for Congress are estimated. ${ }^{19}$ We also include state random effects because those members of Congress representing states farther from Washington D.C. (or those with fewer options for air travel) may find it more difficult to be present, and may therefore be more likely to propose fewer bills.

In each model, the main effects of Extraversion, Emotional Stability, and Conscientiousness are all positive and significant at conventional levels, suggesting that members with high values of these personality traits will propose more bills on average, in line with Hypotheses 1, 2, and

\footnotetext{
${ }^{19}$ Note that we follow the mutlilevel modeling nomenclature with respect to the distinction between fixed and random effects. Fixed effects are effects that are assumed to be constant across the multilevel structure. Random effects are effects that are allowed to vary by subgroups.
} 
3. However, the significant coefficients on the interactions between these traits and Extremism suggest the effects of these personality traits on bill proposal rates are conditional on ideological extremity. To address this, the top pane of Figure 1 presents the predicted counts of bill proposals, varying both Extraversion and Extremism, the middle pane presents the same results conditional on Emotional Stability and Extremism, and the bottom pane examines how Conscientiousness and Extremism interact.

[Table 2 about here.]

[Figure 1 about here.]

For centrists (Extremism $\approx 0$ ), the relationship between personality and bill proposals is quite strong, as the predicted number of bills proposed increases from about 8 to about 63 when $E x$ traversion is moved from its minimum value to its maximum value, ceteris paribus. When Emotional Stability is moved from its minimum value to its maximum value, ceteris paribus, the predicted number of bills proposed increases from about 10 to about 68. Finally, when Conscientiousness is moved from its minimum value to its maximum value, ceteris paribus, the predicted number of bills proposed increases from about 5 to about 124 . For extremists (Extremism $\approx 0.8$ ), the relationship between personality and bill proposals is much weaker, or even nonexistent. For these members of Congress, Extraversion has essentially no effect, as moving it from its minimum value to its maximum value increases the predicted number of bills proposed from about 15 to about 17, ceteris paribus. The results are a bit stronger for Emotional Stability and Conscientiousness, though far less pronounced than for centrist legislators. Moving Emotional Stability (Conscientiousness) from its minimum value to its maximum increases the number of predicted bills proposed from about 10 (7) to about 29 (38). For mainstream members of Congress (Extrem$i s m \approx 0.4$ ), the effects of personality are less pronounced than for centrists, but more pronounced than for extremists. Collectively, these results suggest that while Extraversion, Emotional Stabil- 
ity, and Conscientiousness are important predictors of members' floor activity, as predicted by Hypotheses 1, 2, and 3, the effect is moderated by ideological extremity.

\section{Sponsoring Style or Sponsoring Substance?}

Of course, the number of bills proposed, while interesting in and of itself, only tells part of the story. Indeed, such an analysis by its very nature must omit nearly any discussion of their content. Are these purely symbolic bills intended to rename local post offices after local figures (for example), or are these more substantive bills geared toward effecting major policy changes? Different types of bills should reflect different underlying goals and should also require varying degrees of effort to successfully shepherd through the legislative process.

To address this, we analyze all bills proposed in the House during the 104th through the 112th Congress. Each bill was categorized using Volden \& Wiseman (2009)'s coding criteria as being ceremonial/symbolic in nature or of substantive importance based on their titles. ${ }^{20}$ Our belief is that the types of bills that legislators decide to sponsor can tell us quite a bit about their preferences for policy payoffs over time. A symbolic or ceremonial bill which serves to raise awareness or affirm a principle requires little effort expended over time due to its simplicity and diminished contention. Symbolic bills can be passed quickly to make a relatively small impact to advance a policy goal, while a substantive piece of legislation promises a bigger impact but requires more work expended over time to realize. Conscientious members of Congress who have a lower discounting of future payoffs should be more likely to choose to introduce and advance substantive legislation rather than expend effort on proposing ceremonial/symbolic bills. This yields Hypothesis 4.

Hypothesis 4 Increased Conscientiousness should be associated with lower rates of sponsorship of

\footnotetext{
${ }^{20}$ Volden \& Wiseman (2009) classify bills as ceremonial/symbolic if any of the following phrases occur in the title: "commemoration, commemorate, for the private relief of, for the relief of, medal, mint coins, posthumous, public holiday, to designate, to encourage, to express the sense of Congress, to provide for correction of, to name, to redesignate, to remove any doubt, to rename, and retention of the name" (11).
} 
ceremonial/symbolic bills.

Table 2 presents the results of a series of logistic regressions; in all of these, the proportion of proposed bills that are ceremonial/symbolic in nature is the dependent variable. ${ }^{21}$ Model 1 simply regresses the dependent variable on the Big Five traits. Models 2 and 3 add additional structural control variables that may affect the desirability of expending one's effort on substantive policy proposals-ideological distance from the floor median as measured by the absolute difference in DW-NOMINATE scores, whether one is in the majority party, seniority, whether one is a committee chairperson, whether one sits on a "power committee" (Appropriations, Rules, and/or Ways and Means), and electoral security as measured by the members's vote share in the previous election. Additionally, Model 2 interacts Distance from Floor Median with all of the Big Five traits, to account for majoritarian theories of Congress that posit those policies closest to the preferences of the median voter are more likely to pass (Krehbiel 1991, Krehbiel 1998). Conversely, Model 3 interacts Majority Party with all of the Big Five traits, to account for theories of Congress suggesting the importance of parties (Aldrich 1995, Cox \& McCubbins 2005, Rohde 1991). ${ }^{22}$ Models 4 through 6 replicate Models 1 through 3, but with the addition of Congress-level random effects. Generally, we posit that higher levels of Conscientiousness should be associated with lower proportions of ceremonial/symbolic bills, though the effect may be mitigated (or enhanced) by structural or ideological influences.

\section{[Table 3 about here.]}

The results in Table 3 broadly support Hypothesis 4. The point estimate on Conscientiousness is negative in all models, statistically significant at all conventional levels in four models, and the

\footnotetext{
${ }^{21}$ We necessarily drop all observations where zero bills were proposed. Because of concerns that this would substantively affect the results, we also estimated a series of Poisson regressions where the dependent variable is the number of ceremonial/symbolic bills each member proposed during each Congress, with an logged offset of one plus the total number of bills proposed per member-Congress dyad. These models allow us to include more observations, and the results are substantively identical to those presented here. However, we present the logistic results-despite the slightly lower $N$-because the interpretation as a proportion is more intuitive, in our opinion.

${ }^{22}$ Because of multicollinearity concerns, we do not include both sets of interactions in the same models.
} 
interaction between Conscientiousness and Distance from Floor Median is negative and significant in the two models where the Conscientiousness main effect does not reach conventional levels of significance. Moreover, Conscientiousness is the only Big Five trait that exhibits statistically significant effects in all estimated models. However, as the interaction terms are significant in several models, we present our results graphically in Figure $2 .{ }^{23}$

[Figure 2 about here.]

As Figure 2 shows, more Conscientious members of the House typically propose proportionally fewer ceremonial/symbolic bills, instead dedicating their energies to more substantive arenas. Moreover, the effect is mitigated by ideological/structural influences. For example, Conscientiousness seems to least affect those who are ideologically aligned with the median voterthat is, those who are most likely to see bills with which they agree pass without their own influence. These members will be able to free ride to a certain extent on the efforts of the ideological middle with some assurance that substantive bills with which they agree will come to the floor. Conversely, those who are further out in the tails of the ideological distribution will be more inclined to propose substantive bills with which they agree-because there will be fewer fellow members of the House on whose efforts they can free ride-so long as they are sufficiently Conscientious. Additionally, those who are farther from the floor median are weakly less likely to propose ceremonial symbolic bills; for those with lower levels of Conscientiousness, the $95 \%$ confidence intervals about the predicted probabilities overlap, and for those with higher levels, those farther from the floor median are statistically distinguishable from those closer to the median and proposing ceremonial bills at lower rates. Substantively similar results are found when we look at the effects of Conscientiousness on the rate of ceremonial/symbolic bill proposals, differentiated by Majority Party Status. In those models, Majority Party Status somewhat mitigates

\footnotetext{
${ }^{23}$ In this figure, all continuous independent variables are held at their means, and all binary independent variables are held at their modal values. In the top pane, Distance from Floor Median is held at a "low" value (10th percentile) and a "high" value (90th percentile).
} 
the effect of Conscientiousness, presumably because of the same free-riding mechanism discussed above. Overall, these results suggest that, in support of Hypothesis 4, Conscientious is an important predictor of the types of bills legislators sponsor, though its effects are conditional on ideological and institutional influences.

\section{Cosponsoring Across the Aisle}

With whom do members of Congress work to ensure passage of their bills? Using data from the 104th-109th Houses, Harbridge \& Malhotra (2011) show that bipartisan cosponsorship rates are negatively correlated with the partisan strength of a district, largely because representatives from safer districts feel less electoral pressure to moderate, and thus engage in bipartisan cosponsorship less often. Conversely, representatives from more centrist-or even hostile-districts engage in bipartisan cosponsorship at higher rates. However, while bipartisan cosponsorship has its electoral purposes, it may also reflect an underlying preference on the part of legislators to work together and pursue tactics that widely distribute benefits. Agreeable legislators should believe that the benefit of others, including other legislators, leads to increased utility for themselves. If a legislator is purely concerned about enacting his or her own policy preferences, believes that implementing those preferences would maximize his re-election prospects, and is ideologically closer to members of his or her own party than members of the other party, he or she has little reason to co-sponsor legislation with members of the other party. ${ }^{24}$ However, as the utility from the office and policy benefits enjoyed by others increases, working with members of the other party-or at least not shutting them out of policy-making-becomes more attractive. An agreeable legislator would prefer to obtain his preferred policy through tactics that benefits others if possible, and bipartisan cosponsorship does exactly that. This yields the following hypothesis:

Hypothesis 5 More Agreeable legislators should co-sponsor more bills with members of the opposing

\footnotetext{
${ }^{24}$ This should hold only for members of the majority and ignores any signaling value from co-sponsorship that may come even if a bill does not pass.
} 
party than less Agreeable legislators.

However, we should not ignore the electoral incentives at play here. To wit, if we treat Openness to Experience as a measure of legislators' risk preference, we can expect members of Congress who score highly on the Openness to Experience measure to pursue their policy objectives through political tactics which are inherently risky in nature. Accordingly, members with low Openness to Experience scores will seek to avoid risks, and should accordingly be willing to expend effort to insure themselves against known risks. members with districts which have a high degree of support for the other party face a very risky election every cycle. Cosponsoring legislation with members of the other party provides these members with a degree of insurance, as the more they cosponsor legislation with the other party, the more often they can claim that they are representing the interests of their constituents who do not share their partisan affiliation. However, this comes at the cost of credibly supporting other partisan bills which may produce more preferable policy for the member. More risk averse members will be more willing to pay the cost of this election insurance and accept less policy utility. Accordingly, we expect Openness to Experience to be negatively related with bipartisan cosponsorship, and this effect should be influenced by the partisanship of the member's district. Stated formally, our hypothesis is as follows:

Hypothesis 6 As the number of votes in a member's district increases for the presidential candidate of the opposing party increases, less Open members should be more likely to cosponsor legislation with members of the opposing party.

Finally, we posit that Emotional Stability should have very strong associations with how responsive legislators are to district partisanship. As Emotional Stability is associated with lower degrees of risk aversion, we have reason to believe this trait should have a similar relationship with bipartisan cosponsorship as Openness to Experience. We should expect less stable members of Congress to be more risk averse and thus more willing to sacrifice other sources of utility in 
order to insure themselves as their districts more heavily support candidates of the other party. Drawing from the logic outlined just above for Openness to Experience, we obtain the following hypothesis:

Hypothesis 7 As the number of votes in a member's district increases for the presidential candidate of the opposing party increases, less stable members should be more likely to cosponsor legislation with members of the opposing party.

Accordingly, Table 4 shows the results from a series of regressions predicting bipartisan cosponsorship, controlling for District Partisan Strength-operationalized as the mean two-party presidential vote in the previous two elections by the party of the incumbent representative-in addition to the DYNAPER scores. Models 1, 2, and 3 present the results of binomial regressions where the dependent variable is the proportion of a member's cosponsored bills that were cosponsored by bipartisan coalitions, and Models 4, 5, and 6 present the results of Poisson regressions where the dependent variable is the number of bills cosponsored by a member that were included in bipartisan coalitions. ${ }^{25}$ Like Harbridge \& Malhotra (2011), we code members as engaging in a bipartisan cosponsorship if he or she cosponsors a bill on which at least $20 \%$ of the bill's cosponsors are from the party opposite the party of the bill's original sponsor. We also estimate models with Congress-level random effects.

[Table 4 about here.]

Because we are estimating models with interaction terms, interpretation of the effects of Agreeableness and Emotional Stability on bipartisan cosponsorship is dependent on the partisanship of one's district. Given this and the fact that the interpretation of the magnitude of binomial and Poisson coefficients is not immediately straightforward, we present our results-along with $95 \%$ confidence intervals-graphically in Figure 3. Holding all other personality traits at

\footnotetext{
${ }^{25} \mathrm{An}$ offset of one plus the logged total number of cosponsored bills is used for the Poisson regressions in Table 4.
} 
their mean values, we see that going from the minimum to the maximum values of Agreeableness increases the proportion of cosponsored bills in bipartisan cosponsorship coalitions across the board, as predicted by Hypothesis 5, with the largest effects felt in the safest districts, suggesting that Agreeableness may mitigate any incentives to avoid cosponsorships when the chief hurdle to reelection is not the general electorate, but rather the primary electorate. Similar dynamics hold when we look at the number of bipartisan cosponsored bills.

[Figure 3 about here.]

The effect of Emotional Stability on bipartisan cosponsorship is also as predicted by Hypothesis 7. Highly stable legislators are the least responsive to district partisanship. Moreover, they engage in bipartisan cosponsorship at lower rates than less stable legislators in the same type of district as well as similarly stable legislators in more marginal districts. Moreover, unstable legislators in the most marginal districts engage in bipartisan cosponsorship at higher rates than stable legislators in the same type of district as well as similarly unstable legislators in safer districts. Like with Agreeableness, substantively identical dynamics hold when we look at the number of bipartisan cosponsored bills.

However, the effect of Openness on bipartisan cosponsorship is not as predicted, and we find no support for Hypothesis 6. Indeed, in no model is the main effect of Openness-or the interaction between Openness and District Partisanship-significant at conventional levels. Moreover, the magnitudes of the coefficients are much smaller than the other coefficients in the model, suggesting that the null result is likely due to a true lack of an effect as opposed to a lack of sufficient data. Generally, however, we find strong support that electoral incentives combine with personality traits to affect the rates at which members of the House engage in bipartisan cosponsorship. 


\section{Beyond Bill Sponsorship: A Preview}

While bill sponsorship is an important Congressional duty, members of Congress do much more than that. They work behind the scenes to ensure passage of their bills, they vote on bills, they organize themselves into committees, they determine amongst themselves who should lead their caucuses and in what capacities, they choose to run (or not) for reelection, they choose particular campaign styles and tactics, they choose different ways of communicating with their constituents, and many other decisions-both inside and outside the halls of Congress-that are so varied they cannot be adequately captured within the confines of a single paper. Nonetheless, while our argument here has focused on bill sponsorship in particular, our larger argument is that personality traits, to a certain extent, affect every decision made by members of Congress. To illustrate the applications beyond bill sponsorship, we look at how two other aspects of the legislative process-getting bills passed and voting on bills-are affected by legislator personality.

\section{Getting Bills Passed}

We first look at how effective individual members of Congress are at shepherding their policy proposals through the legislative process. To do so, we utilize Volden and Wiseman's $(2009,2013)$ legislative effectiveness scores (LES) from the 104th-112th Houses. These scores measure how effective each individual member of the House is by examining both a) the importance of bills sponsored by individual members of Congress, as well as b) how far each bill makes it through the legislative process. These factors are then weighted and aggregated to create the LES index. ${ }^{26}$ Higher values indicate greater effectiveness and lower values indicate the opposite.

As mentioned earlier, more Conscientious members of Congress should be more likely to engage in behavior wherein the rewards may not materialize in the immediate term. We argue

\footnotetext{
${ }^{26}$ For each session of Congress, the LES index is normalized to have a mean of one and minimum of zero. The standard deviation in each session is approximately one, though the index is heavily right-skewed. For a more thorough explanation of how the LES index is generated, see Volden \& Wiseman (2009).
} 
that another example of this is the legislative process itself. As it generally takes a significant amount of time for bills to progress through the legislative process-if they do at all-members of Congress that work to ensure passage of their bills should be, to some extent, motivated by future payoffs. These members of Congress should be more effective, at least insofar as the LES index is concerned. Conversely, those who place less emphasis on future payoffs-that is, those who are less Conscientious-should be less inclined to spend time shepherding their bills through the process and should be less effective, at least as measured by the LES index.

Table 5 presents the results of a series of linear regressions; in all of these, the LES index is the dependent variable. Otherwise, the models are identical in terms of independent variables and random effects to those estimated with the proportion of ceremonial/symbolic bills as the dependent variable. ${ }^{27}$ Generally, we posit that Conscientiousness should be associated with higher levels of legislative effectiveness, though the effect may be mitigated by structural or ideological influences.

[Table 5 about here.]

In the models with just the Big Five traits as independent variables (Models 1 and 4), the coefficient on Conscientiousness is positive and significant, indicating that more conscientious members have higher levels of legislative effectiveness, as measured by the LES index. However, once additional independent variables are included, and the effects of the Big Five traits are allowed to be conditioned on ideological (Distance from Floor Median) or structural (Majority Party Status) influences, the effects of Conscientiousness become much more nuanced. Because these models include interaction terms, a graphical representation of the effects is preferred. Figure 4 plots the effect of Conscientiousness, conditional on Majority Party Status. ${ }^{28}$ While the effect of

\footnotetext{
${ }^{27}$ Because the LES scores are normalized at the Congress level, there is very little variation that Congress-level effects would be able to pick up. Therefore, in contrast to many of the other analyses in this paper, we utilize member-level as opposed to Congress-level effects.

${ }^{28}$ In this figure, all continuous independent variables are held at their means, and all binary independent variables are held at their modal values.
} 
Conscientiousness on Legislative Effectiveness is positive and substantively strong when members of Congress are in the majority party, the effect of Conscientiousness is effectively zero for minority party members. Similar effects hold when we plot the effects of Distance from Floor Median on Legislative Effectiveness. Collectively, these results suggest that when other conditions are in place that make it easier (or at least possible) to be effective legislators, Conscientiousness can play a major role; otherwise, however, it does not seem as if the parameters revealed by personality trait measures can overcome institutional or ideological obstacles.

[Figure 4 about here.]

\section{Voting on Bills}

Finally, we look at how personality affects members' willingness to vote on bills. In a recent review of the literature on roll call voting, Clinton (2012) reminds scholars that absenteeism and abstention in roll call voting has the potential to bias our roll call estimates of ideology. This problem is only material if abstention is missing-at-random; that is, missingness is idiosyncratic and not correlated with the nature of votes themselves. Ultimately, Clinton (2012) notes that abstentions are unlikely to cause much of a problem empirically since they account for fewer than $5 \%$ of all votes.

Nevertheless, absenteeism and abstention are a substantively interesting when considering how the Big Five come in to play. Recall that we hypothesized that Conscientious lawmakers are less likely to be absent for votes, as such absence constitutes shirking a central responsibility of their careers. To be sure, abstention is sometimes unavoidable for family reasons, health, or even to tend to district needs. That said, if we aggregate to the Congress-member level, such idiosyncratic absences will constitute (on average) a small portion of total absences.

To explore this idea, we gathered data on absenteeism on every roll call vote from the 104th110th Congresses, aggregated up to the Congress-member level. Table 6 shows the results from 
a series of Poisson regressions of the number of abstentions by Congress-member (offset by the number of votes that Congress) and a series of binomial logistic regression predicting the rate of abstention, all controlling for DW-NOMINATE and DYNAPER scores. For both sets of regressions, the first model is a baseline case, the second allows for the influence of ideological extremism, and the third adds in random effects for Congress, state, and member. Not surprisingly, the coefficient on Conscientiousness is negative and significant across specifications, indicating that more Conscientious members abstain less often. However, the coefficients on the main effect for Extremism and the interaction between Extremism and Conscientiousness are significant in all models.

Therefore, in order to visualize these results more clearly, Figure 5 displays the predicted absence rates, varying Conscientiousness and Extremism but fixing other covariates at their means (or mode, in the case of Gender). For centrists (Extremism $\approx 0$ ), we see that going from the minimum to the maximum values of Conscientiousness lowers the predicted absence rate from just over $4 \%$ to about $2 \%$. For mainstream members of Congress (Extremism $\approx 0.4$ ), the effect is more pronounced, with the absence rate decreasing from just under $7 \%$ to about $2 \%$. Finally, for extremists (Extremism $\approx 0.8)$, there is a very large effect, as predicted absence rate decreases from just under $10 \%$ to about $2 \%$. Collectively, these results suggest that while Conscientiousness is an important predictor of members' absence rates, the effect is intensified by ideological extremity. Similar dynamics hold when we look at the number of total number of absences, as opposed to the absenteeism rate.

[Table 6 about here.]

[Figure 5 about here.] 


\section{Discussion and Next Steps}

We have found compelling evidence that the Big Five personality trait measures are associated with legislators' use of bill sponsorship tactics to pursue their policy objectives. We have also shown evidence that the Big Five personality trait measures are associated with a variety of other behaviors in the U.S. Congress. Our analysis suggests that more extraverted members sponsor more bills than their less extraverted colleagues, particularly when members have the option of lazily free-riding off of other members with similar ideal points in the ideological center; the same is true for conscientious and emotionally stable members. Conscientious members tend to sponsor lower proportions of symbolic or ceremonial bills which provide a quickly-achieved-but often weak-policy win. They are also more effective at shepherding their bills through the legislative process and are less likely to miss roll call votes. Agreeable members of Congress choose to cosponsor more often with members of the other party, in line with higher degrees of trust. However, more emotionally stable members in highly partisan districts do not tend to use bipartisan cosponsorship as insurance against potential tough elections in the future. Interestingly, Openness to Experience does not have much of a relationship with the aspects of bill sponsorship we examined, but this may be due to the fact that Openness is the weakest of all of the Big Five personality trait dimensions in the Five-Factor Model (Costa \& McCrae 1992).

The results presented in this article demonstrate the applicability of legislator personality measures in predicting legislative use of one of the most central tactics available to legislators other than voting, but early analysis suggests that the use of a wide variety of other legislative tactics are related to Big Five personality trait measures. While we have focused in this paper on tactics used to pursue policy motivations, other behaviors that take place over the course of the political lifespan are associated with the Big Five personality trait measures. These tentative findings suggest that personality trait measures and the underlying economic parameters they capture may also be connected with decisions to run for and ability to win higher office, ability 
to raise campaign funds and preferences in spending those funds, legislators' choices in utilizing traditional and social media, legislative effectiveness, propensity to utilize various procedures and rules in the chamber, positions in the chamber and decisions to retire. Each of these behaviors reflect (directly or indirectly) the decisions that legislators make in the context of varying costs and motivations toward policy, office, and prestige. The authors are currently in the process of finalizing these analyses and presenting their results for further discussion and theoretical development.

In many of the analyses presented in this article, significant interactive effects were found between personality traits, policy preferences, and institutional characteristics. We expect that, in many cases, individuals' ideological positions influence the importance of the underlying parameters that we claim personality trait measures capture. In fact, the frequent presence of interactive relationships between personality and ideology suggest that policy preferences change the decisions legislators face. Additionally, our results add support to the current body of evidence suggesting that the personality traits and policy preferences of individuals are correlated.

These findings raise the question of whether the parameters behind personality traits (directly or indirectly) lead to the adoption of policy preferences, policy preferences cause the adoption of the parameters behind personality traits, if both personality traits and policy preferences share a common cause, or even if there are bi-directional relationships. In future work, we intend to examine the nature of this relationship between ideology and personality more closely. Estimation of legislator ideology in a manner that accounts for the influence of personality on vote choice-along with investigation into the relationships between personality traits and weaker DW-NOMINATE dimensions-would be a contribution to this research program.

The theoretical underpinning for this paper was largely drawn from the emerging literature on the Big Five and economic parameters produced by the economics and personality psychology literature using laboratory experiments. This paper assumes that personality trait measures capture underlying preferences, skills and beliefs that influence the decisions of rational individ- 
uals without making explicit claims about what exact parameters each trait captures and to what degree. It appears likely that Conscientiousness and Openness to Experiences are particularly associated with time preferences and a particular type of risk aversion emphasizing cognitive dissonance, respectively. Furthermore, while both Extraversion and Emotional Stability are correlated with risk preferences, extrapolation from the literature suggests that extroverts suffer from a slower capacity to update when exposed to new information, and that individuals with low Emotional Stability have prior beliefs with much higher variance than others. Finally, Agreeableness appears to be associated with a higher weight on utility gained from fairness and fulfilling the norms of selfless statesmanship.

At the moment, we are hesitant to go too far beyond the existing literature and hypothesize on the basis of informed speculation. However, we anticipate that new findings in experimental economics and personality psychology will allow us to gain a more nuanced understanding of the parameters correlated with each trait. The Five-Factor Model was developed as a means of describing the important dimensions of action and intent that distinguish between the behavior of individuals. We believe the Big Five personality measures can point to more refined ways of thinking about individuals' preferences and access to information that have important influence on the behavior of legislators. For example, the type of risk aversion captured by (the inverse of) Emotional Stability may be substantively different from the type of risk aversion captured by Openness to Experience. Given the robust differentiation between the Big Five personality trait measures, if there is a substantive difference in the type of parameter associated with multiple traits, that difference is likely to have important effects of behavior which we intend to incorporate into our research agenda.

As we believe that personality trait measures are useful because they capture important preferences, skills, and beliefs which influence behavior, there is a great opportunity for future scholars to develop more precise measures of these parameters for legislators and other political elites. Time, risk, and social preferences, along with the cost of effort, are extremely important pa- 
rameters for individual decision-making in economics, and assuming imperfect information, the information available to individuals is an essential parameter to consider as well. There are currently efforts going on among experimental economists to develop survey measures which can be used to estimate risk, time and social preferences (Falk et al. 2012). We hope that this progress can be extended to the development of text-based and other passive direct measures of these key parameters which could be used in the future to study legislators.

A more immediately accessible and promising pathway to follow in refining our measures is to dig deeper and examine the lower level facets included in each of the Big Five, and adapt our text-based measures to estimate these facets. For example, Compassion and Politeness, two facets of Agreeableness, have been found to predict political attitudes in opposite directions (Anderson et al. 2011). These and other subordinate facets in the expanded Five-Factor Model should be examined further to assess what distinctive preferences and skills they may measure. While we tend to focus on the parameters economists claim are most important, we are eager to learn from what more expanded personality trait systems indicate are important determinants of behavior. Alternative and expanded personality trait systems offer a great opportunity for future text-based measurement and identification of important parameters.

Finally, our results suggest there exists an opportunity to enrich our models of legislative behavior to incorporate personality traits, and to empirically test the implications of existing models of legislative behavior (such as legislative bargaining) that already incorporate some of these key parameters associated with personality trait measures. It may prove fruitful to incorporate the various flavors of uncertainty and preferences over uncertainty into models of legislative voting, accounting for not only uncertainty as to the policy positions of the status quo and proposals on the left-right dimension, but to also allow proposals to possess other traits, such as riskiness, payoff streams over time, and difficulty of implementation.

Overall, we believe advances in estimating legislators' personalities offer new insights into why politicians may pursue their policy objectives with the tactics they choose. We believe that 
personality traits capture underlying preferences and limitations on information which are associated with officeholders' decisions to select some political tactics and eschew others in a way that preserves the rationality of these individuals. We have found substantial evidence that personality is associated with the key non-voting tactic of sponsoring bills, and presented evidence that additional tactical decisions are associated with personality trait measures. These findings, which hold even when controlling for measures of legislator ideology, suggest that voters have reason to pay attention to their representatives' personalities. These findings also suggest that additional work to connect personality with specific legislative actions-both theoretically and empirically-are in order, and will significantly enrich our understanding of how citizens, their elected officials, and policy interact with one another. 


\section{References}

Aberbach, Joel D. \& Bert A. Rockman. 2000. In the Web of Politics: Three Decades of the U.S. Federal Executive. Washington, DC: Brookings Institution Press.

Aldrich, John H. 1995. Why Parties?: The Origin and Transformation of Political Parties in America. Chicago: University Of Chicago Press.

Almlund, Mathilde, Angela Duckworth, James Heckman \& Tim Kautz. 2011. "Personality Psychology and Economics." NBER Working Paper (w16822).

Aluja, Anton, Óscar García \& Luis F García. 2002. “A comparative study of Zuckerman’s three structural models for personality through the NEO-PI-R, ZKPQ-III-R, EPQ-RS and Goldberg's 50-bipolar adjectives." Personality and Individual Differences 33(5):713-725.

Anderson, Jon, Stephen Burks, Colin DeYoung \& Aldo Rustichini. 2011. Toward the integration of personality theory and decision theory in the explanation of economic behavior. In Unpublished manuscript. Presented at the IZA workshop: Cognitive and non-cognitive skills.

Barbaranelli, Claudio, Gian Vittorio Caprara, Michele Vecchione \& Chris R Fraley. 2007. "Voters' personality traits in presidential elections." Personality and Individual Differences 42(7):1199-1208.

Ben-Ner, Avner, Amit Kramer \& Ori Levy. 2008. "Economic and hypothetical dictator game experiments: Incentive effects at the individual level." The Journal of Socio-Economics 37(5):1775-1784.

Borghans, Lex, James J Heckman, Bart HH Golsteyn \& Huub Meijers. 2009. “Gender differences in risk aversion and ambiguity aversion." Journal of the European Economic Association 7(23):649-658. 
Caprara, Gian Vittorio, Claudio Barbaranelli \& Philip G. Zimbardo. 2002. "When Parsimony Subdues Distinctiveness: Simplified Public Perceptions of Politicians' Personality.” Political Psychology 23(1):77-95.

Charness, Gary \& Matthew Rabin. 2002. "Understanding Social Preferences with Simple Tests.” Quarterly Journal of Economics 117(3):817-869.

Clinton, Joshua D. 2012. "Using roll call estimates to test models of politics." Annual Review of Political Science 15:79-99.

Costa, Paul T \& Robert R McCrae. 1992. "Normal personality assessment in clinical practice: the NEO Personality Inventory." Psychological assessment 4(1):5-13.

Cox, Gary W. \& Mathew D. McCubbins. 2005. Setting the Agenda: Responsible Party Government in the U.S. House of Representatives. Cambridge, U.K.: Cambridge University Press.

Daly, Michael, Colm P Harmon \& Liam Delaney. 2009. "Psychological and biological foundations of time preference." Journal of the European Economic Association 7(2-3):659-669.

DeYoung, Colin G, Jacob B Hirsh, Matthew S Shane, Xenophon Papademetris, Nallakkandi Rajeevan \& Jeremy R Gray. 2010. “Testing Predictions From Personality Neuroscience Brain Structure and the Big Five.” Psychological Science 21(6):820-828.

Dietrich, Bryce J, Scott Lasley, Jeffery J Mondak, Megan L Remmel \& Joel Turner. 2012. “Personality and legislative politics: The Big Five trait dimensions among US state legislators.” Political Psychology 33(2):195-210.

Dohmen, Thomas, Armin Falk, David Huffman \& Uwe Sunde. 2008. "Representative trust and reciprocity: prevalence and determinants." Economic Inquiry 46(1):84-90. 
Dohmen, Thomas, Armin Falk, David Huffman \& Uwe Sunde. 2010. "Are Risk Aversion and Impatience Related to Cognitive Ability?” The American Economic Review 100(3):12381260.

Enelow, James M. \& Melvin J. Hinich. 1982. "Nonspatial Candidate Characteristics and Electoral Competition." The Journal of Politics 44(1):115-130.

Evans, Anthony M \& William Revelle. 2008. "Survey and behavioral measurements of interpersonal trust." Journal of Research in Personality 42(6):1585-1593.

Eysenck, Hans Jürgen. 1967. The Biological Basis of Personality. Springfield, IL: Thomas Publishing.

Eysenck, Hans Jurgen. 1991. "Dimensions of personality: 16, 5 or 3?-Criteria for a taxonomic paradigm." Personality and individual differences 12(8):773-790.

Falk, Armin, Anke Becker, Thomas Dohmen, David Huffman \& Uwe Sunde. 2012. An experimentally validated preference module. Technical report Working Paper.

Ferguson, Eamonn, James J Heckman \& Philip Corr. 2011. "Personality and economics: Overview and proposed framework." Personality and Individual Differences 51(3):201-209.

Funk, Carolyn L. 1996. "The impact of scandal on candidate evaluations: An experimental test of the role of candidate traits." Political Behavior 18(1):1-24.

Funk, Carolyn L. 1997. "Implications of political expertise in candidate trait evaluations." Political Research Quarterly 50(3):675-697.

Funk, Carolyn L. 1999. "Bringing the Candidate into Models of Candidate Evaluation.” Journal of Politics 61(3):700-720. 
Furnham, Adrian, Jeremy Monsen \& Gorkan Ahmetoglu. 2009. "Typical intellectual engagement, Big Five personality traits, approaches to learning and cognitive ability predictors of academic performance." British Journal of Educational Psychology 79(4):769-782.

Gailmard, Sean \& John W. Patty. 2007. "Slackers and Zealots: Civil Service, Policy Discretion, and Bureaucratic Expertise." American Journal of Political Science 51(4):873-889.

Gerber, Alan S, Gregory A Huber, David Doherty \& Conor M Dowling. 2011. "The big five personality traits in the political arena." Annual Review of Political Science 14:265-287.

Golbeck, Jennifer, Cristina Robles, Michon Edmondson \& Karen Turner. 2011. Predicting personality from twitter. In Privacy, security, risk and trust (passat), 2011 ieee third international conference on and 2011 ieee third international conference on social computing (socialcom). IEEE pp. 149-156.

Goldberg, Lewis R. 1990. “An Alternative "Description of Personality": The Big-Five Factor Structure." Journal of Personality and Social Psychology 59(6):1216-1229.

Goldberg, Lewis R. 1992. "The development of markers for the Big-Five factor structure." Psychological assessment 4(1):26-42.

Graziano, William G \& Renée M Tobin. 1997. Agreeableness. In Handbook of Personality Psychology, ed. Robert Hogan, John Johnson \& Stephen Briggs. Academic Press.

Graziano, William G \& Renée M Tobin. 2002. "Agreeableness: Dimension of personality or social desirability artifact?” Journal of personality 70(5):695-728.

Groseclose, Tim, Steven D. Levitt \& James M. Snyder. 1999. “Comparing Interest Group Scores across Time and Chambers: Adjusted ADA Scores for the U.S. Congress.” The American Political Science Review 93(1):33-50. 
Harbridge, Laurel \& Neil Malhotra. 2011. "Electoral Incentives and Partisan Conflict in Congress: Evidence from Survey Experiments." American Journal of Political Science 55(3):494-510.

Holian, David B. \& Charles Prysby. 2014. "Candidate Character Traits in the 2012 Presidential Election." Presidential Studies Quarterly 44(3):484-505.

Hollibaugh, Jr., Gary E. 2014. "Vacancies, Vetting, and Votes: A Unified Dynamic Model of the Appointments Process." Journal of Theoretical Politics Forthcoming.

Hollibaugh, Jr., Gary E., Gabriel Horton \& David E. Lewis. 2014. “Presidents and Patronage.” American Journal of Political Science Forthcoming.

Huber, John D. \& Nolan McCarty. 2004. "Bureaucratic Capacity, Delegation, and Political Reform." American Political Science Review 98(3):481-494.

John, Oliver P, Richard W Robinson \& Lawrence A Pervin. 2010. Handbook of Personality: Theory and Research. Third ed. New York: The Guilford Press.

Judge, Timothy A, Amir Erez, Joyce E Bono \& Carl J Thoresen. 2002. "Are Measures of SelfEsteem, Neuroticism, Locus of Control, and Generalized Self-Efficacy Indicators of a Common Core Construct?" Journal of Personality and Social Psychology 83(3):693-710.

Kinder, Donald R, Mark D Peters, Robert P Abelson \& Susan T Fiske. 1980. "Presidential prototypes." Political Behavior 2(4):315-337.

Krehbiel, Keith. 1991. Information and Legislative Organization. Ann Arbor: University of Michigan Press.

Krehbiel, Keith. 1998. Pivotal Politics: A Theory of U.S. Lawmaking. Chicago: University of Chicago Press. 
Larsen, Randy J \& Timothy Ketelaar. 1989. “Extraversion, neuroticism and susceptibility to positive and negative mood induction procedures." Personality and Individual Differences 10(12):1221-1228.

Lewis, David E. 2008. The Politics of Presidential Appointments: Political Control and Bureancratic Performance. Princeton, NJ: Princeton University Press.

Lewis, David E. 2009. "Revisiting the Administrative Presidency: Policy, Patronage, and Agency Competence." Presidential Studies Quarterly 39(1):60-73.

Li, Jamy \& Mark Chignell. 2010. "Birds of a feather: How personality influences blog writing and reading." International Journal of Human-Computer Studies 68(9):589-602.

Mairesse, François \& Marilyn A Walker. 2008. Trainable Generation of Big-Five Personality Styles through Data-Driven Parameter Estimation. In ACL. pp. 165-173.

Mairesse, François \& Marilyn A Walker. 2010. “Towards personality-based user adaptation: psychologically informed stylistic language generation." User Modeling and User-Adapted Interaction 20(3):227-278.

Mairesse, François, Marilyn A Walker, Matthias R Mehl \& Roger K Moore. 2007. “Using Linguistic Cues for the Automatic Recognition of Personality in Conversation and Text." J. Artif. Intell. Res.(JAIR) 30:457-500.

McCrae, Robert R. 1994. “Openness to experience: Expanding the boundaries of Factor V." European Journal of Personality 8(4):251-272.

Moe, Terry M. 1985. The Politicized Presidency. In The New Direction in American Politics, ed. John E. Chubb \& Paul E. Peterson. Washington, DC: Brookings Institution Press. 
Mondak, Jeffery J, Matthew V Hibbing, Damarys Canache, Mitchell A Seligson \& Mary R Anderson. 2010. "Personality and civic engagement: An integrative framework for the study of trait effects on political behavior." American Political Science Review 104(1):85-110.

Mondak, Jeffrey J. 1995. "Competence, integrity, and the electoral success of congressional incumbents." Journal of Politics 57:1043-1069.

Nathan, Richard P. 1983. The Administrative Presidency. New York: John Wiley \& Sons.

Norman, Warren T. 1963. "Toward an adequate taxonomy of personality attributes: Replicated factor structure in peer nomination personality ratings." The Journal of Abnormal and Social Psychology 66(6):574-583.

Ozer, Daniel J \& Veronica Benet-Martinez. 2006. "Personality and the prediction of consequential outcomes." Annual Review of Psychology 57:401-421.

Pearce-McCall, Debra \& Joseph P Newman. 1986. "Expectation of success following noncontingent punishment in introverts and extraverts." Journal of personality and social psychology 50(2):439-446.

Pennebaker, James W \& Laura A King. 1999. "Linguistic styles: language use as an individual difference." Journal of personality and social psychology 77(6):1296-1312.

Pennebaker, James W, Martha E Francis \& Roger J Booth. 2001. "Linguistic inquiry and word count: LIWC 2001." Mabway: Lawrence Erlbaum Associates 71:2001.

Poole, Keith T. \& Howard Rosenthal. 1997. Congress: A political-economic history of roll call voting. New York: Oxford University Press.

Rohde, David W. 1991. Parties and Leaders in the Postreform House. Chicago: University of Chicago Press. 
Rotter, Julian B. 1990. “Internal Versus External Control of Reinforcement: A Case History of a Variable." American Psychologist 45(4):489-493.

Saroglou, Vassilis. 2002. "Religion and the five factors of personality: A meta-analytic review." Personality and Individual Differences 32(1):15-25.

Saucier, Gerard. 1994. "Mini-markers: A brief version of Goldberg's unipolar Big-Five markers.” Journal of personality assessment 63(3):506-516.

Schuller, Björn, Stefan Steidl, Anton Batliner, Felix Burkhardt, Laurence Devillers, Christian Müller \& Shrikanth Narayanan. 2013. "Paralinguistics in speech and language-state-ofthe-art and the challenge." Computer Speech E Language 27(1):4-39.

Silvester, Jo, Madeleine Wyatt \& Ray Randall. 2014. "Politician personality, Machiavellianism, and political skill as predictors of performance ratings in political roles." Journal of Occupational and Organizational Psychology 87(2):258-279.

Stokes, Donald E. 1963. "Spatial Models of Party Competition." The American Political Science Review 57(2):368-377.

VandenBos, Gary R. 2007. APA Dictionary of Psychology. American Psychological Association.

Volden, Craig \& Alan E Wiseman. 2009. "Legislative Effectiveness in Congress." Manuscript, The Ohio State University .

Volden, Craig, Alan E. Wiseman \& Dana E. Wittmer. 2013. "When Are Women More Effective Lawmakers Than Men?” American Journal of Political Science 57(2):326-341.

Webb, Edward. 1915. Character and intelligence: An attempt at an exact study of character. Vol. Supplement 1 . 
Zuckerman, Marvin, Elizabeth A Kolin, Leah Price \& Ina Zoob. 1964. "Development of a sensation-seeking scale." Journal of consulting psychology 28(6):477-482. 


\section{Appendix: Are the Estimates of Personality a Function of Ide- ology?}

One natural concern with using potentially ideologically-tinged legislative speeches to estimate personality is that our estimates of the Big Five may be simply summaries of legislator ideology. In Table 7, we present the results from a regression of common space DW-NOMINATE scores (Poole \& Rosenthal 1997) on the Big Five. Positive DW-NOMINATE scores are conservative and negative are liberal. These results do show the same general findings in the psychology literature (Barbaranelli et al. 2007): namely, those open to new experience and agreeable are liberal and conscientious and emotionally stable legislators are conservative. Note, however, that the model $R^{2}$ is quite low, suggesting that the personality traits alone do not account for large amount of the variance in roll-call ideology scores. Figures 6-10 reiterate this point graphically. Each plot shows one of the Big Five plotted with DW-NOMINATE scores by Congress. We see that there is generally a loose relationship between the Big Five and ideology. In turn, this suggests that whatever theoretical concerns about the dependence of the Big Five on ideology or the ideological content of the legislative record are not a problem empirically.

[Table 7 about here.]

[Figure 6 about here.]

[Figure 7 about here.]

[Figure 8 about here.]

[Figure 9 about here.]

[Figure 10 about here.] 
As a final check of robustness, we consider the correlations between members of the Big Five. A correlation heatmap of this is found in Figure 11. Since we found both conscientiousness and emotional stability correlate with conservatism and that the other three traits correlate with liberalism, we should look to this figure to see if conscientiousness and emotional stability positively correlate with one another but negatively correlate with the other traits. Fortunately, this is not the case. For example, openness, the strongest predictor of liberalism is positively correlated with both agreeableness and conscientiousness. Similar findings hold across the other traits. In sum, this suggests that the DYNAPER scores are not just replications of ideology.

[Figure 11 about here.] 
Figure 1: Extraversion, Emotional Stability, Conscientiousness, and Bill Proposals
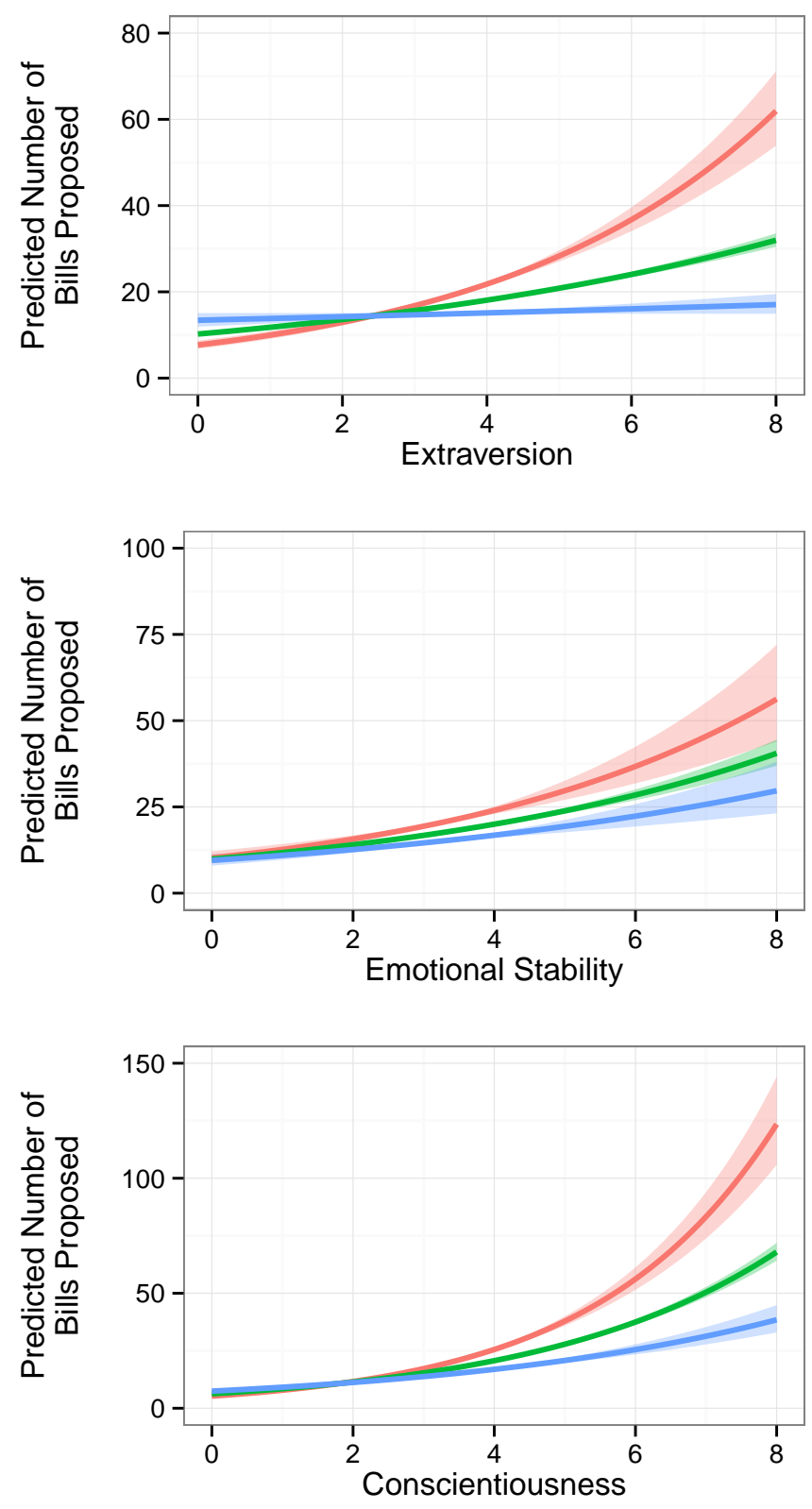

Extremism $\square$ Centrist $Z^{-}$Mainstream $\square$ Extremist

N.B. The predicted value plot fixes all parameters but the stated personality traits and Extremism at their means. Ideological extremism is varied from its minimum value 0 to its median $(0.4)$ and 99th percentile (0.8). Point estimates are represented by solid lines and $95 \%$ confidence intervals are shaded. 
Figure 2: Conscientiousness and Ceremonial Bill Proposals
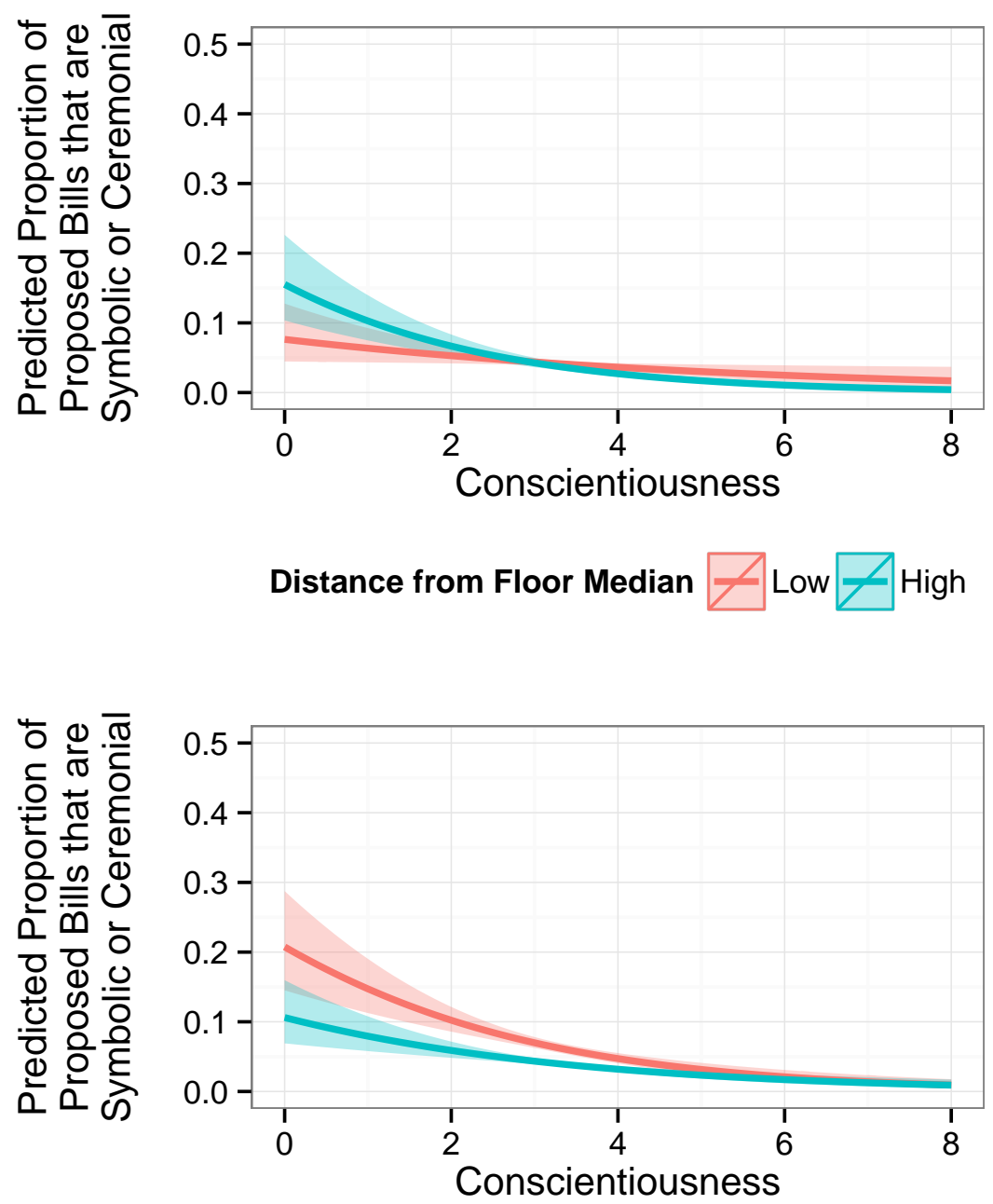

Party Status ${ }^{2}$ Minority - Majority 
Figure 3: Agreeableness, Emotional Stability, and Bipartisan Cosponsorship
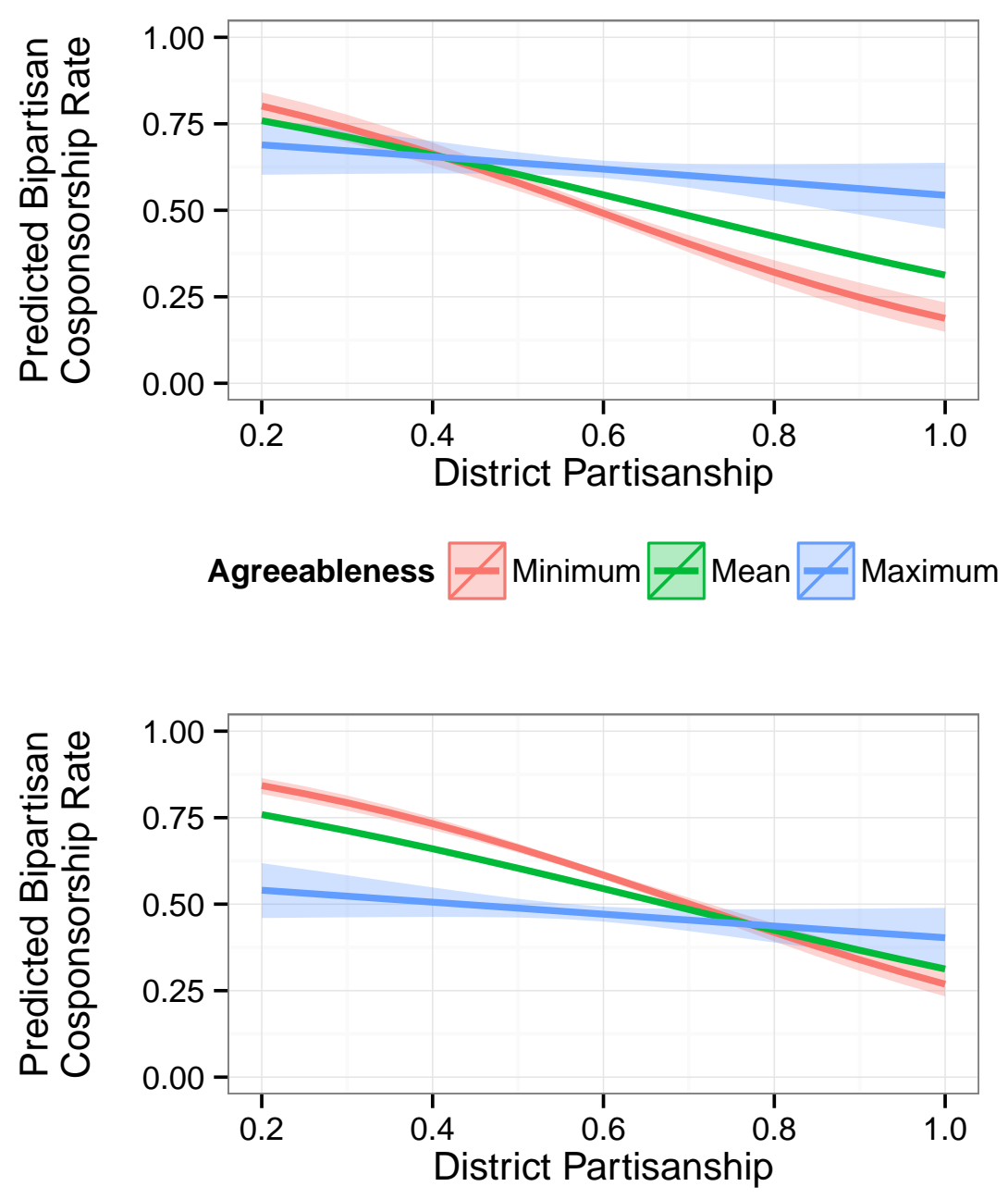

Emotional Stability $z^{2}$ Minimum ${ }^{2}$ Mean ${ }^{2}$ Maximum

N.B. The predicted value plot fixes all parameters but the stated personality traits and District Partisanship at their means. Point estimates are represented by solid lines and $95 \%$ confidence intervals are shaded. 
Figure 4: Conscientiousness and Legislative Effectiveness

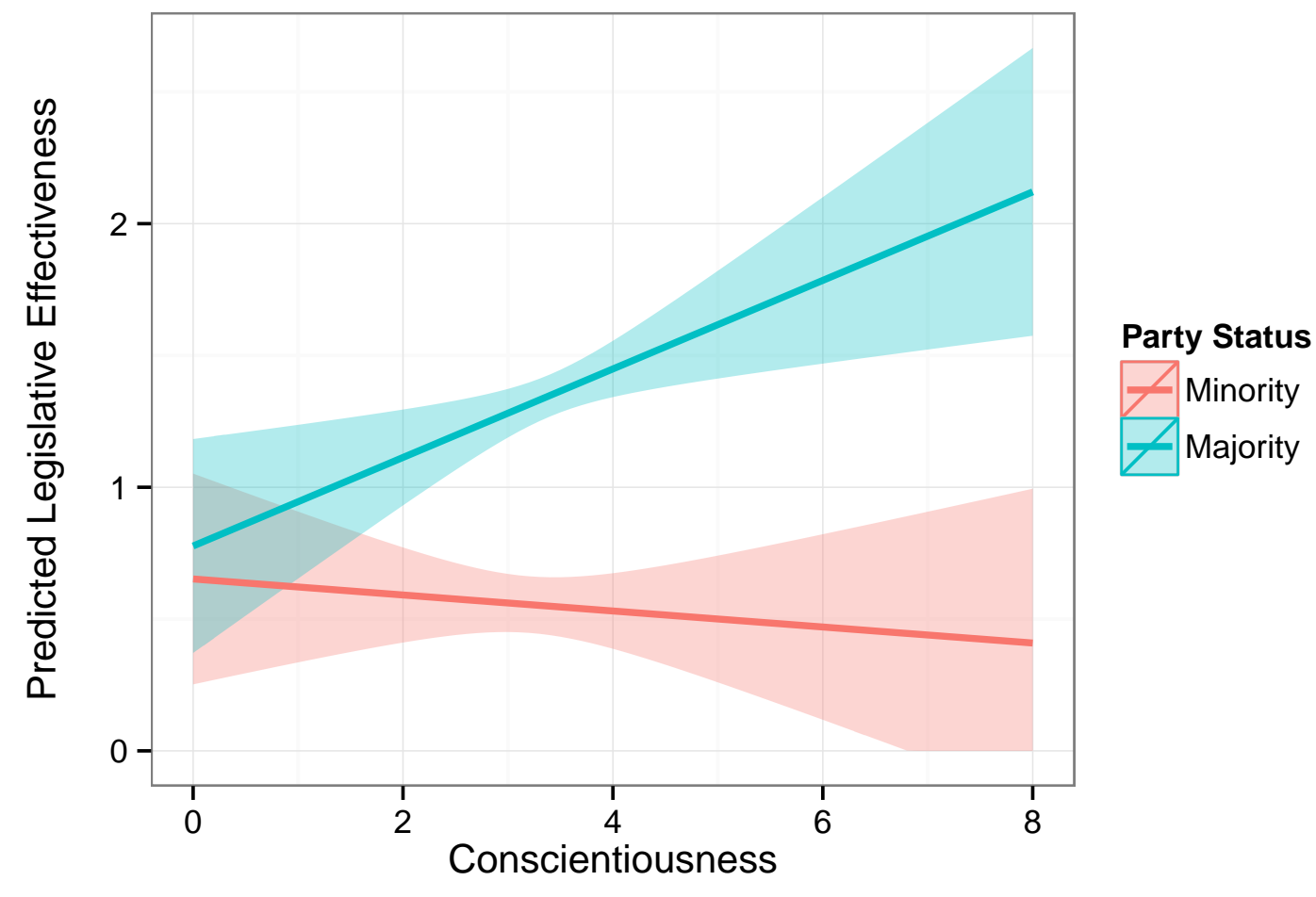


Figure 5: Conscientiousness and Absences

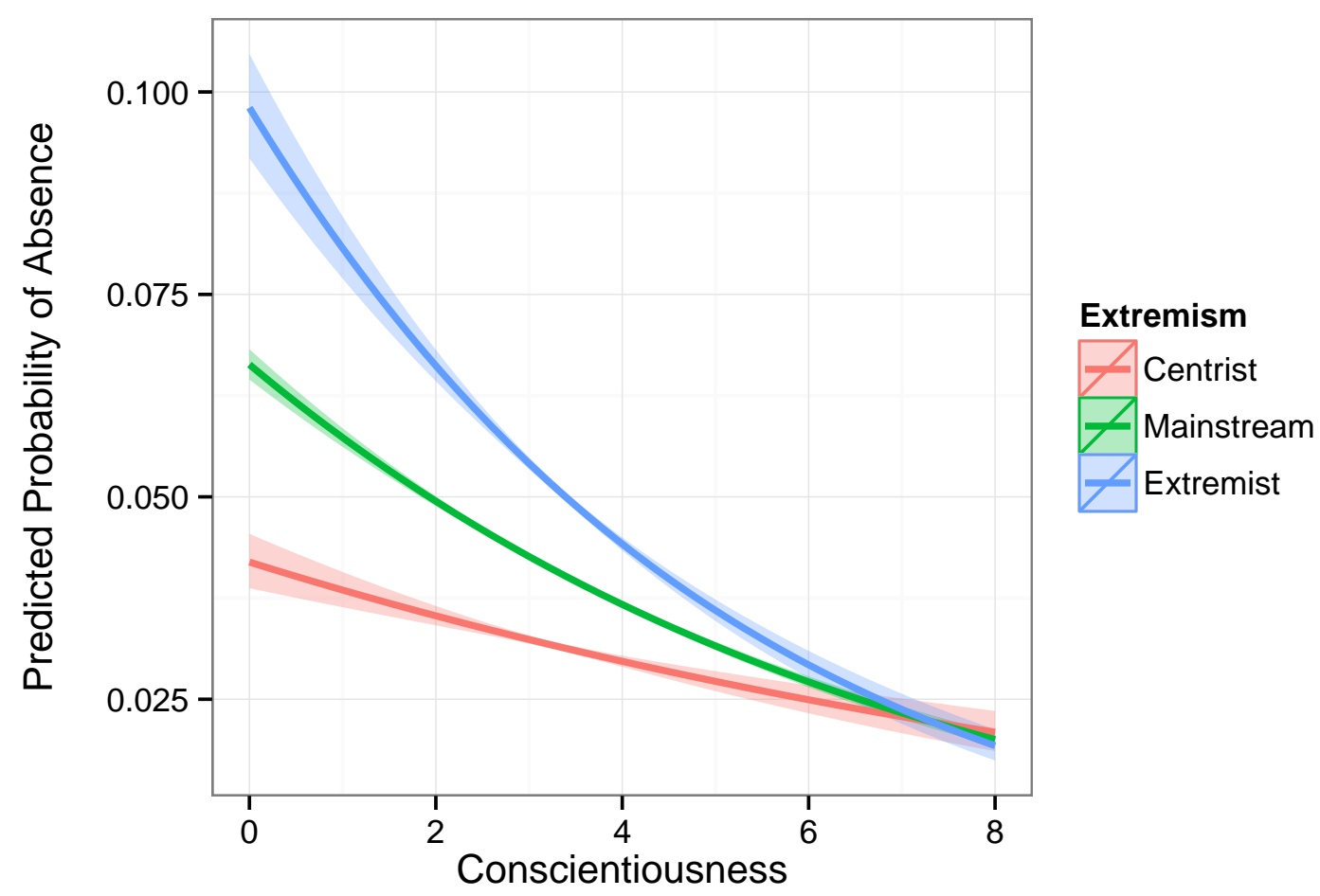

N.B. The predicted value plot fixes all parameters but Conscientiousness and Extremism at their means. Point estimates are represented by solid lines and $95 \%$ confidence intervals are shaded. 
Figure 6: Openness vs. DW-NOMINATE by Congress
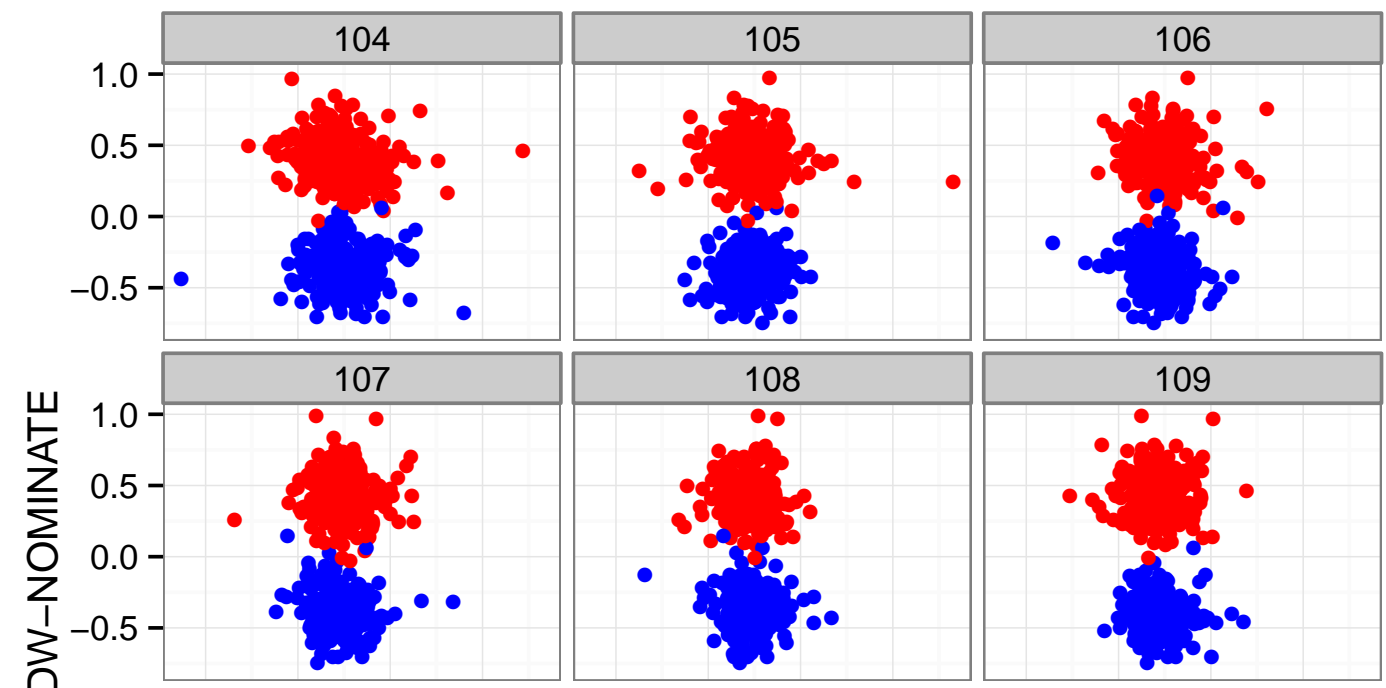

Party
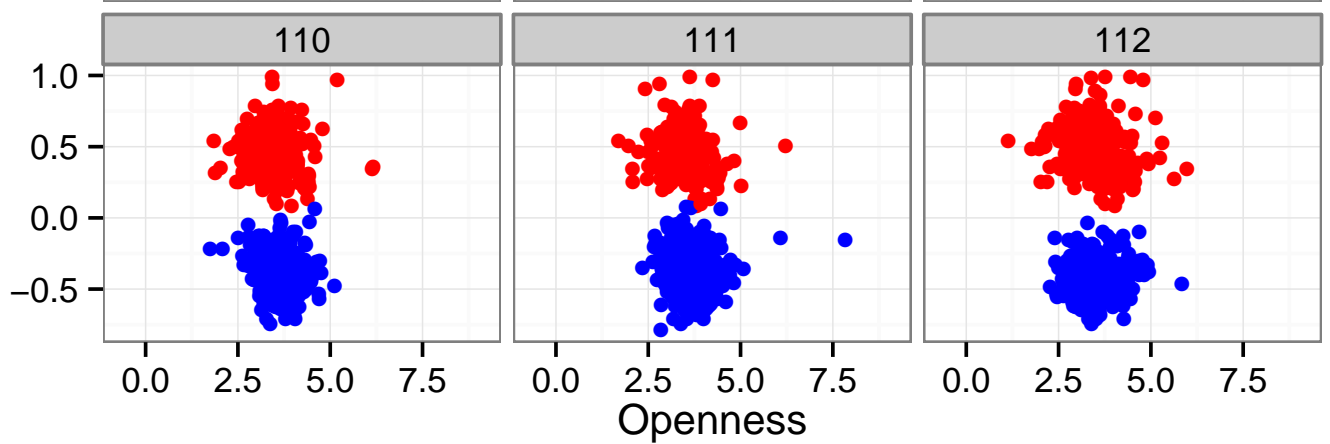

- Democrat

- Republican 
Figure 7: Conscientiousness vs. DW-NOMINATE by Congress
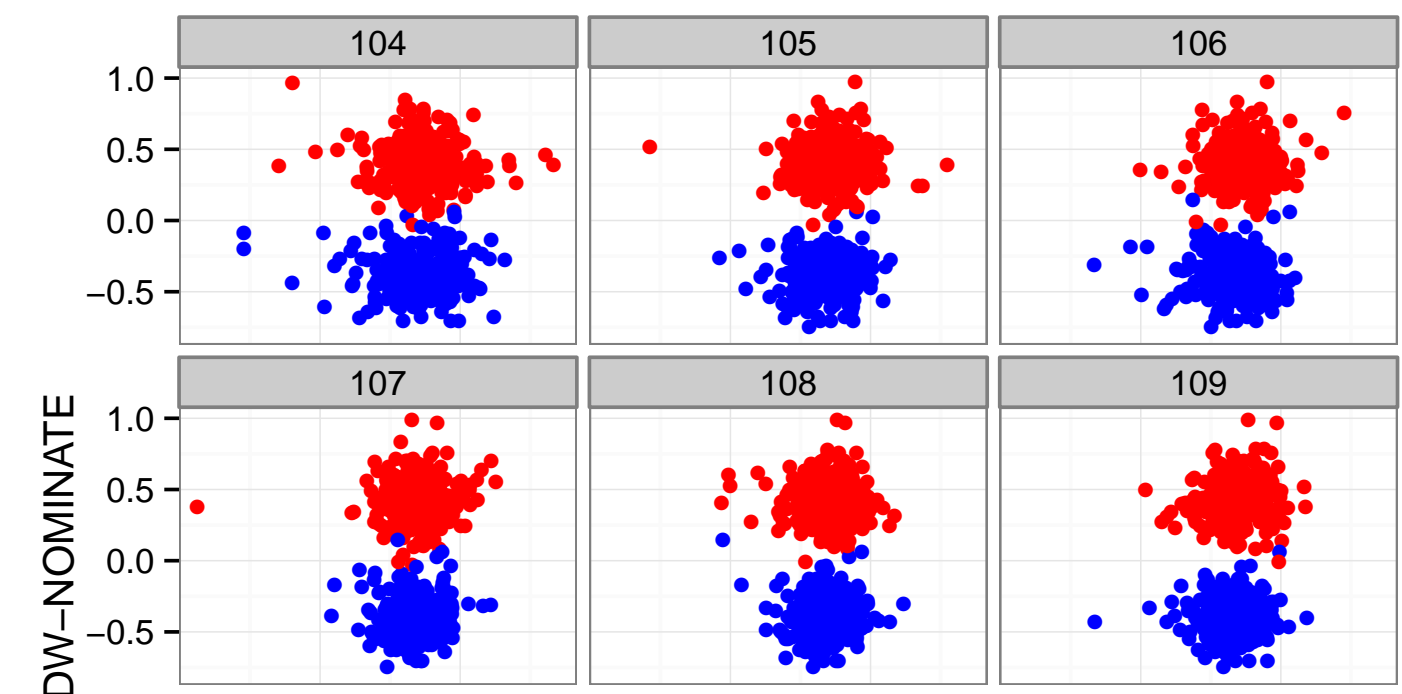

Party
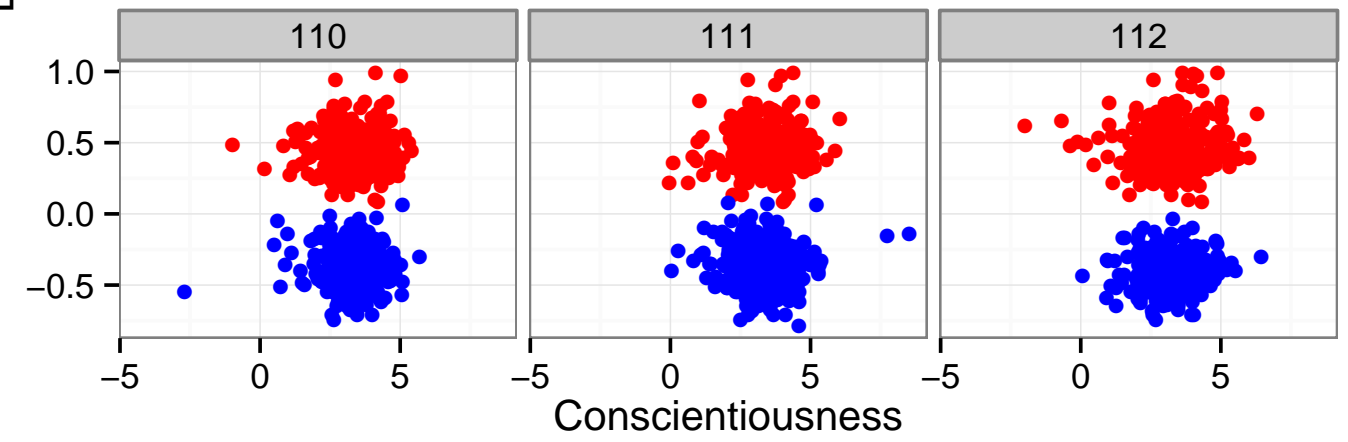

- Democrat

- Republican 
Figure 8: Extraversion vs. DW-NOMINATE by Congress
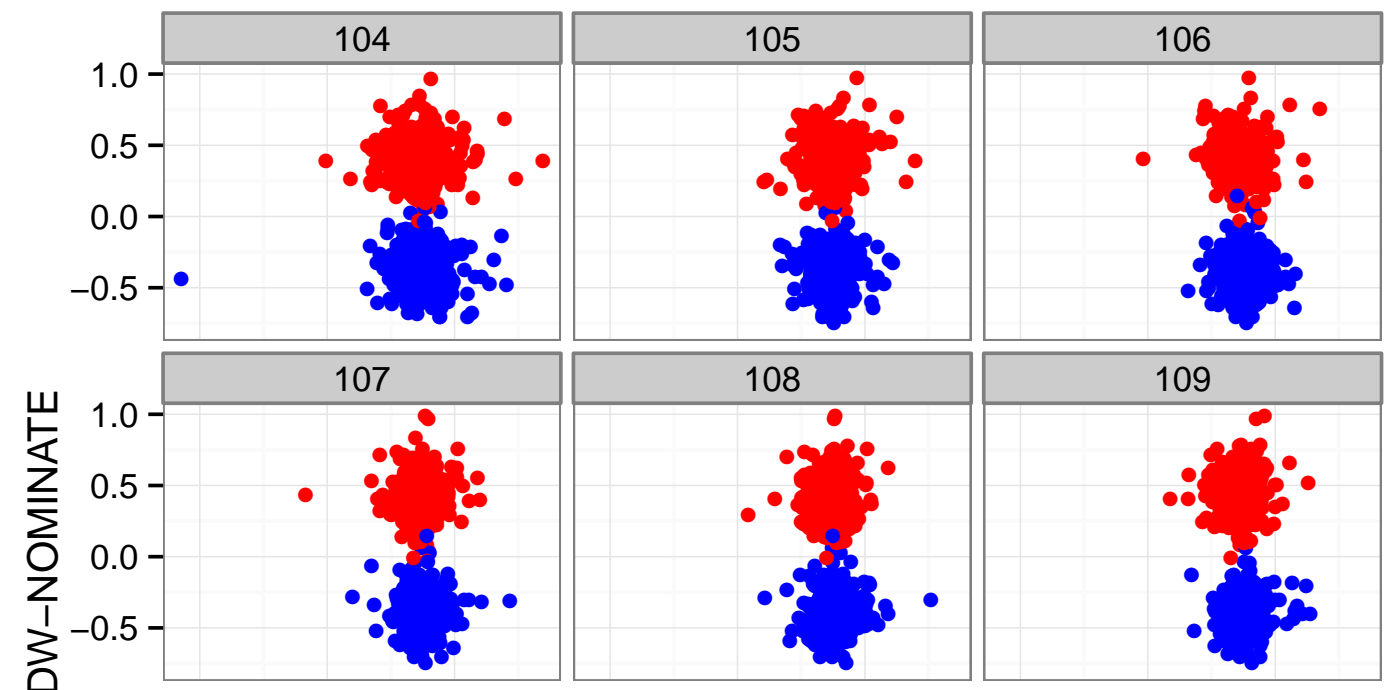

Party

- Democrat

- Republican
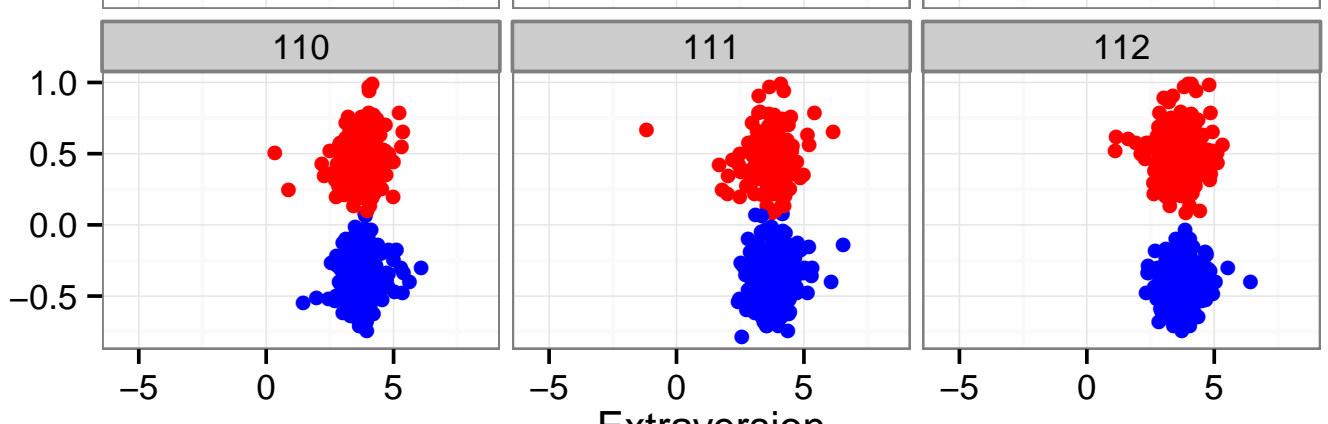

Extraversion 
Figure 9: Agreeableness vs. DW-NOMINATE by Congress

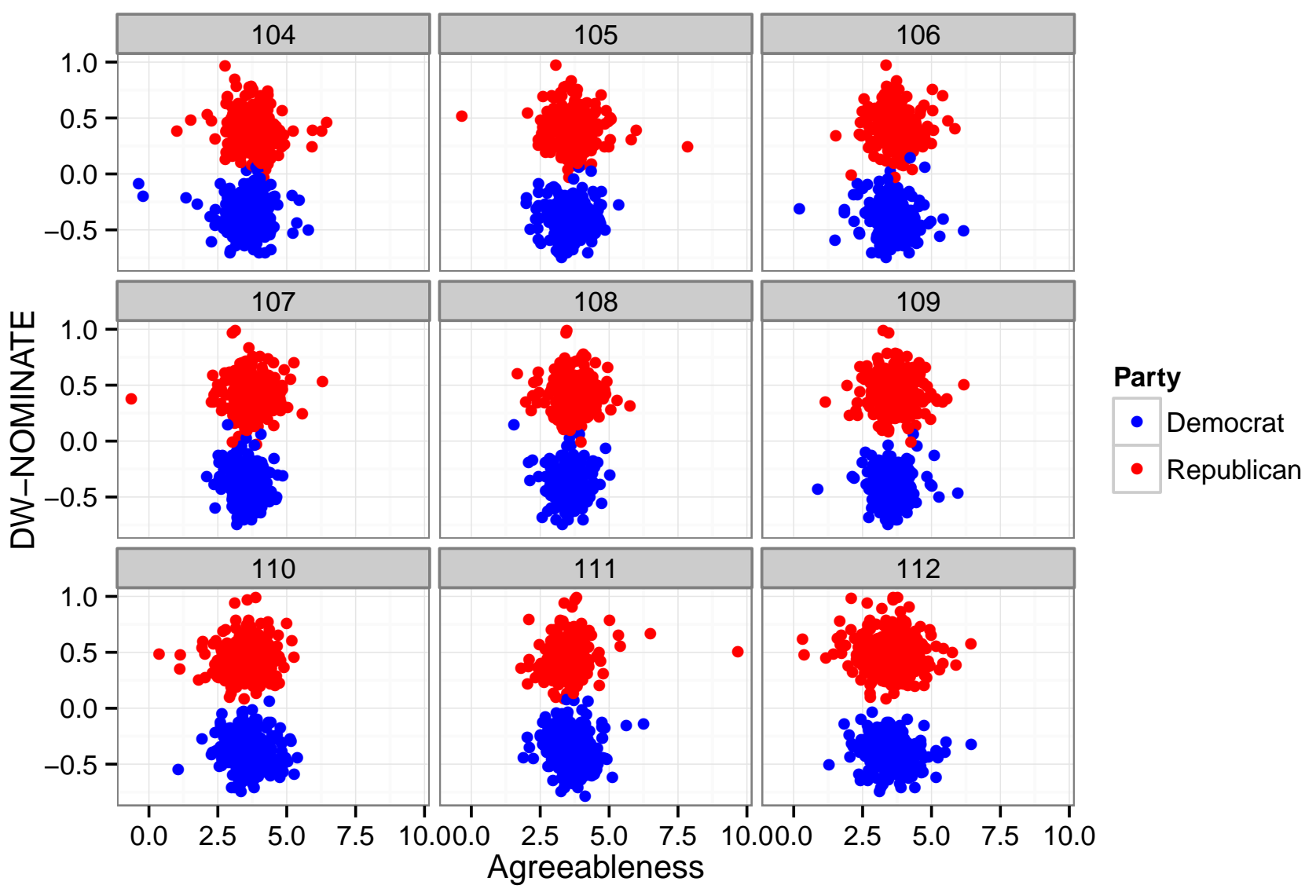


Figure 10: Emotional Stability vs. DW-NOMINATE by Congress
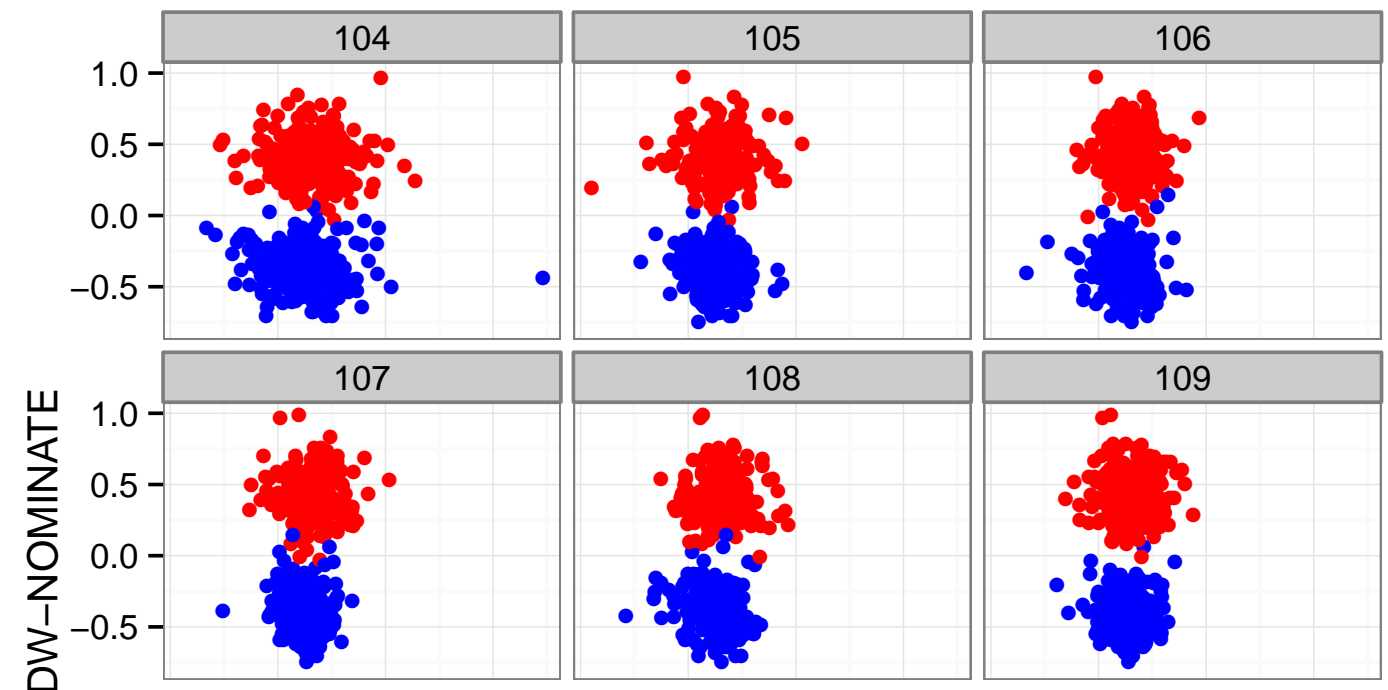

Party

- Democrat

- Republican

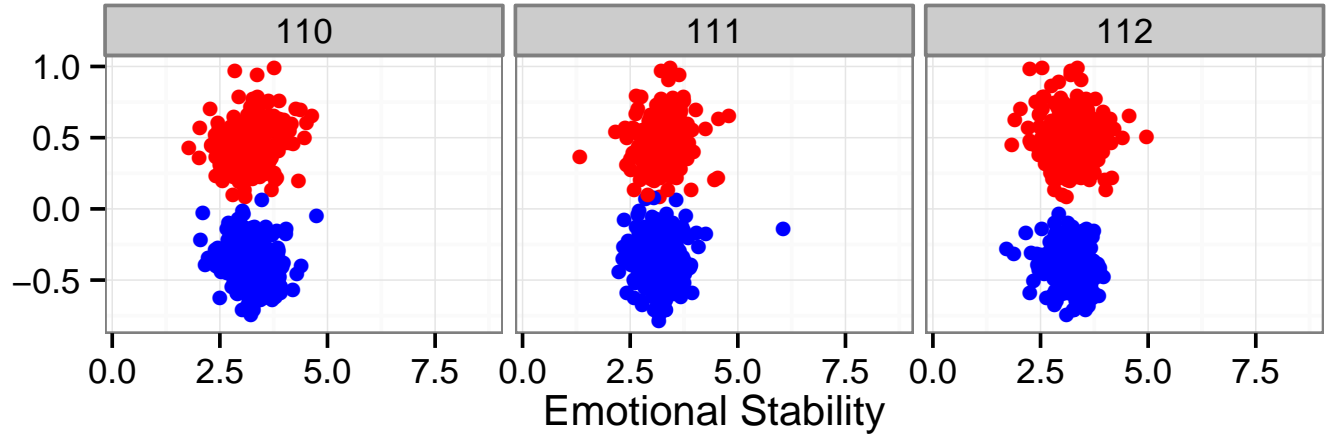


Figure 11: Intra-Big Five Correlations

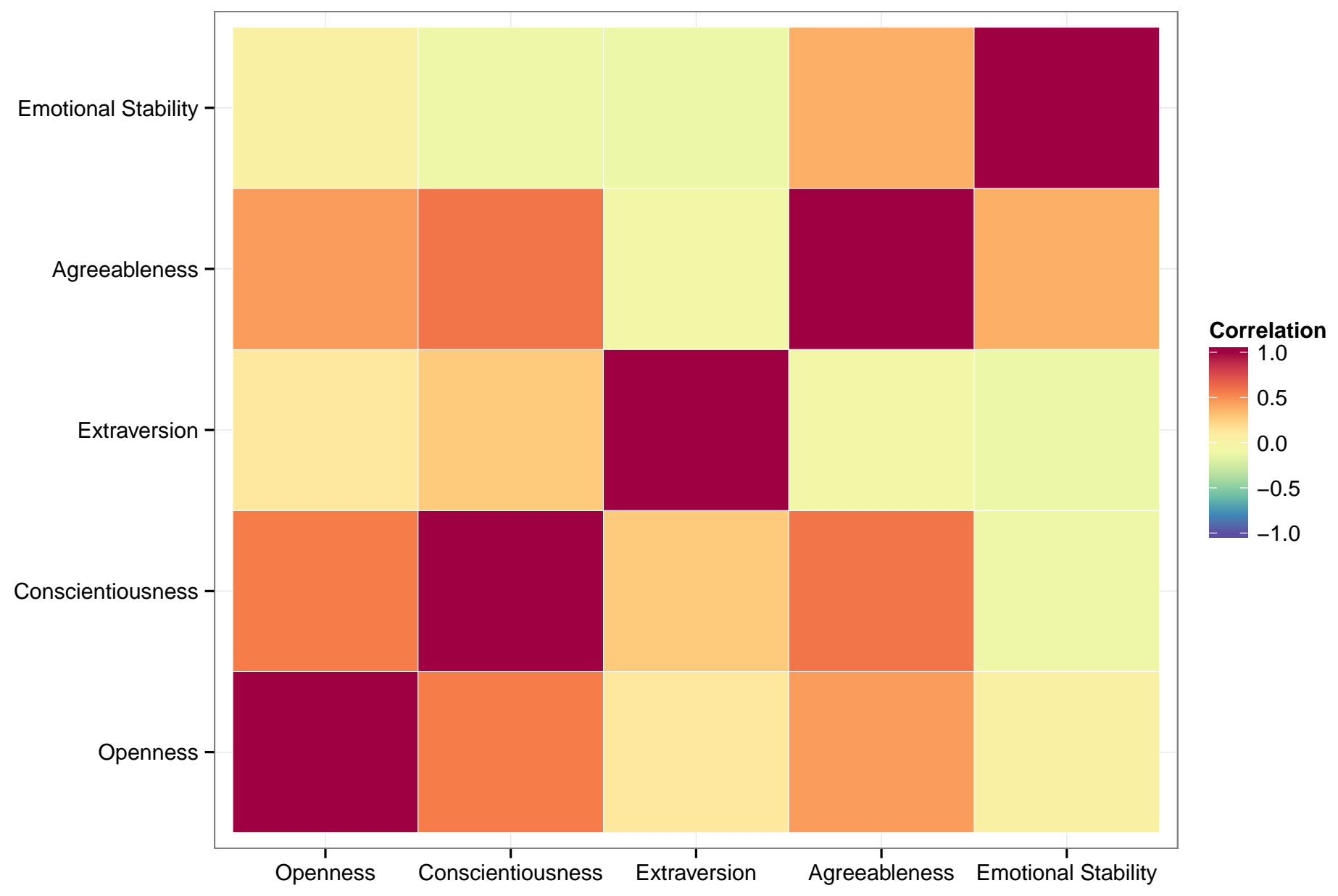




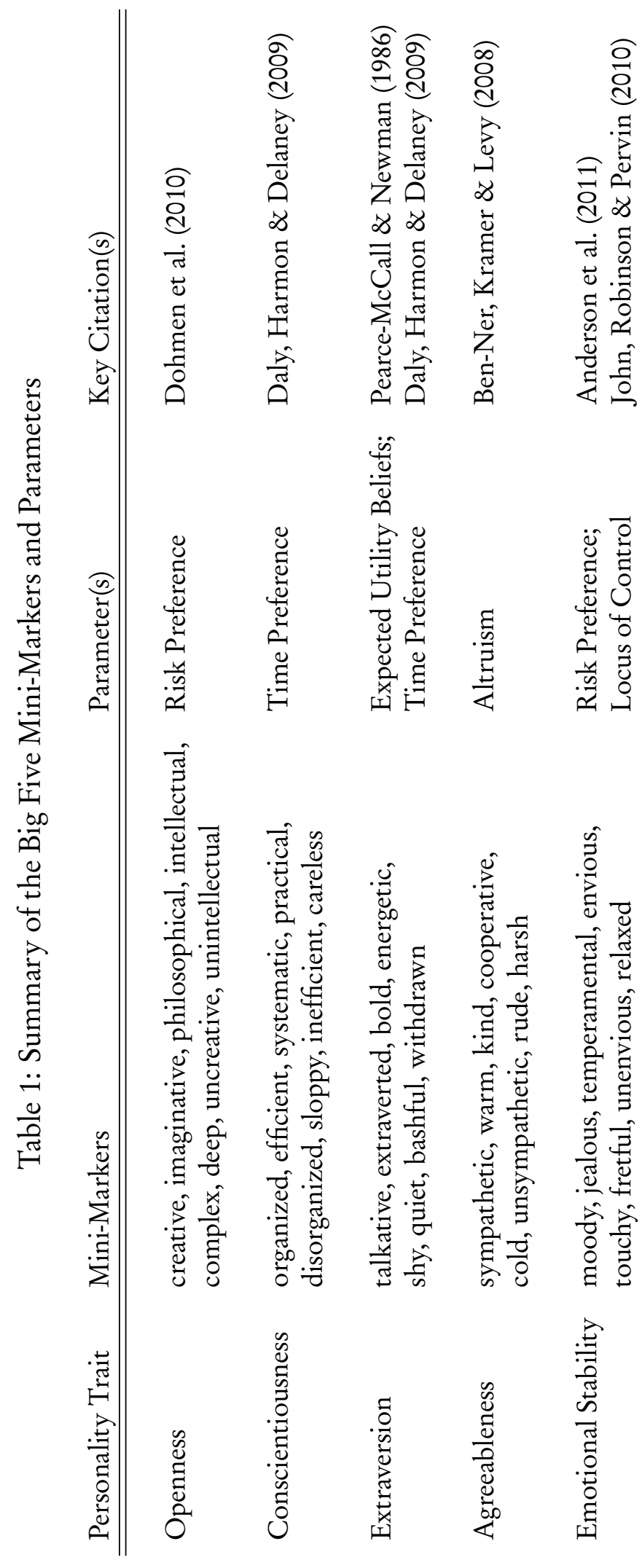


Table 2: Predicting Number of Bills Proposed by Congress

\begin{tabular}{|c|c|c|c|c|c|c|}
\hline & Model 1 & Model 2 & Model 3 & Model 4 & Model 5 & Model 6 \\
\hline$\overline{\text { Openness }}$ & $\begin{array}{l}0.007 \\
(0.007)\end{array}$ & $\begin{array}{c}-0.270^{* * *} \\
(0.019)\end{array}$ & $\begin{array}{c}-0.270^{* * *} \\
(0.019)\end{array}$ & $\begin{array}{l}-0.008 \\
(0.008)\end{array}$ & $\begin{array}{c}-0.313^{* * *} \\
(0.020)\end{array}$ & $\begin{array}{c}-0.313^{* * *} \\
(0.020)\end{array}$ \\
\hline Conscientiousness & $\begin{array}{l}0.307^{* * *} \\
(0.006)\end{array}$ & $\begin{array}{l}0.409^{* * *} \\
(0.017)\end{array}$ & $\begin{array}{l}0.396^{* * *} \\
(0.017)\end{array}$ & $\begin{array}{l}0.309^{* * *} \\
(0.007)\end{array}$ & $\begin{array}{l}0.396^{* * *} \\
(0.018)\end{array}$ & $\begin{array}{l}0.382^{* * *} \\
(0.018)\end{array}$ \\
\hline Extraversion & $\begin{array}{l}0.131^{* * *} \\
(0.006)\end{array}$ & $\begin{array}{l}0.266^{* * *} \\
(0.016)\end{array}$ & $\begin{array}{l}0.263^{* * *} \\
(0.016)\end{array}$ & $\begin{array}{l}0.132^{* * *} \\
(0.006)\end{array}$ & $\begin{array}{l}0.295^{* * *} \\
(0.017)\end{array}$ & $\begin{array}{l}0.292^{* * *} \\
(0.017)\end{array}$ \\
\hline Agreeableness & $\begin{array}{c}-0.307^{* * *} \\
(0.009)\end{array}$ & $\begin{array}{c}-0.258^{* * *} \\
(0.028)\end{array}$ & $\begin{array}{c}-0.267^{* * * *} \\
(0.028)\end{array}$ & $\begin{array}{c}-0.266^{* * * *} \\
(0.010)\end{array}$ & $\begin{array}{c}-0.112^{* * *} \\
(0.028)\end{array}$ & $\begin{array}{c}-0.121^{* * *} \\
(0.028)\end{array}$ \\
\hline Emotional Stability & $\begin{array}{l}0.177^{* * *} \\
(0.010)\end{array}$ & $\begin{array}{l}0.263^{* * *} \\
(0.026)\end{array}$ & $\begin{array}{l}0.214^{* * *} \\
(0.026)\end{array}$ & $\begin{array}{l}0.179^{* * *} \\
(0.010)\end{array}$ & $\begin{array}{l}0.290^{* * *} \\
(0.028)\end{array}$ & $\begin{array}{l}0.241^{* * *} \\
(0.028)\end{array}$ \\
\hline Extremism & - & $\begin{array}{l}0.142 \\
(0.249)\end{array}$ & $\begin{array}{l}-0.241 \\
(0.248)\end{array}$ & - & $\begin{array}{l}1.218^{* * *} \\
(0.256)\end{array}$ & $\begin{array}{l}0.877^{* * *} \\
(0.255)\end{array}$ \\
\hline $\begin{array}{l}\text { Extremism } \\
\quad \times \text { Openness }\end{array}$ & - & $\begin{array}{l}0.681^{* * *} \\
(0.045)\end{array}$ & $\begin{array}{l}0.697^{* * *} \\
(0.044)\end{array}$ & - & $\begin{array}{l}0.747^{* * * *} \\
(0.047)\end{array}$ & $\begin{array}{l}0.751^{* * * *} \\
(0.046)\end{array}$ \\
\hline $\begin{array}{l}\text { Extremism } \\
\quad \times \text { Conscientiousness }\end{array}$ & - & $\begin{array}{c}-0.249^{* * *} \\
(0.042)\end{array}$ & $\begin{array}{c}-0.246^{* * *} \\
(0.042)\end{array}$ & - & $\begin{array}{c}-0.205^{* * *} \\
(0.043)\end{array}$ & $\begin{array}{c}-0.198^{* * *} \\
(0.043)\end{array}$ \\
\hline $\begin{array}{l}\text { Extremism } \\
\times \text { Extraversion }\end{array}$ & - & $\begin{array}{c}-0.324^{* * *} \\
(0.039)\end{array}$ & $\begin{array}{c}-0.301^{* * *} \\
(0.039)\end{array}$ & - & $\begin{array}{c}-0.389^{* * * *} \\
(0.041)\end{array}$ & $\begin{array}{c}-0.363^{* * *} \\
(0.040)\end{array}$ \\
\hline $\begin{array}{l}\text { Extremism } \\
\quad \times \text { Agreeableness }\end{array}$ & - & $\begin{array}{c}-0.137^{* *} \\
(0.065)\end{array}$ & $\begin{array}{l}-0.118^{*} \\
(0.065)\end{array}$ & - & $\begin{array}{c}-0.401^{* * *} \\
(0.066)\end{array}$ & $\begin{array}{c}-0.382^{* * *} \\
(0.066)\end{array}$ \\
\hline $\begin{array}{l}\text { Extremism } \\
\quad \times \text { Emotional Stability }\end{array}$ & - & $\begin{array}{c}-0.152^{* *} \\
(0.063)\end{array}$ & $\begin{array}{l}-0.092 \\
(0.063)\end{array}$ & - & $\begin{array}{l}-0.208^{* * *} \\
(0.066)\end{array}$ & $\begin{array}{c}-0.150^{* * *} \\
(0.066)\end{array}$ \\
\hline Majority Party Status & - & - & $\begin{array}{l}0.235^{* * *} \\
(0.007)\end{array}$ & - & - & $\begin{array}{l}0.243^{* * *} \\
(0.007)\end{array}$ \\
\hline Female & $\begin{array}{l}0.222^{* * *} \\
(0.010)\end{array}$ & $\begin{array}{c}0.214^{* * * *} \\
(0.010)\end{array}$ & $\begin{array}{l}0.223^{* * * *} \\
(0.010)\end{array}$ & $\begin{array}{l}0.189^{* * * *} \\
(0.010)\end{array}$ & $\begin{array}{c}0.182^{* * * *} \\
(0.010)\end{array}$ & $\begin{array}{l}0.185^{* * *} \\
(0.010)\end{array}$ \\
\hline Age & $\begin{array}{l}0.016^{* * *} \\
(0.000)\end{array}$ & $\begin{array}{l}0.015^{* * *} \\
(0.000)\end{array}$ & $\begin{array}{l}0.016^{* * *} \\
(0.000)\end{array}$ & $\begin{array}{l}0.013^{* * *} \\
(0.000)\end{array}$ & $\begin{array}{c}0.012^{* * * *} \\
(0.000)\end{array}$ & $\begin{array}{l}0.012^{* * *} \\
(0.000)\end{array}$ \\
\hline Constant & $\begin{array}{l}0.825^{* * *} \\
(0.042)\end{array}$ & $\begin{array}{l}0.735^{* * *} \\
(0.107)\end{array}$ & $\begin{array}{l}0.813^{* * * *} \\
(0.106)\end{array}$ & $\begin{array}{l}0.886^{* * *} \\
(0.078)\end{array}$ & $\begin{array}{c}0.357^{* * *} \\
(0.128)\end{array}$ & $\begin{array}{l}0.425^{* * *} \\
(0.128)\end{array}$ \\
\hline Congress RE? & No & No & No & Yes & Yes & Yes \\
\hline State RE? & No & No & No & Yes & Yes & Yes \\
\hline AIC & 65327.981 & 64680.922 & 63618.987 & 38458.346 & 37940.024 & 36828.487 \\
\hline BIC & 65379.701 & 64771.432 & 63715.963 & 38522.997 & 38043.464 & 36938.393 \\
\hline Log Likelihood & -32655.990 & -32326.461 & -31794.494 & -19219.173 & -18954.012 & -18397.244 \\
\hline Deviance & 44719.500 & 44060.440 & 42996.506 & 38438.346 & 37908.024 & 36794.487 \\
\hline Num. obs. & 4746 & 4746 & 4746 & 4746 & 4746 & 4746 \\
\hline
\end{tabular}

Two-tailed tests: ${ }^{\cdots * 1 *} p<0.01, ", p<0.05, " p<0.1$

N.B. Cells are Poisson estimates predicting bill proposals with standard errors in parentheses. Observations are at the Congress-member level. 
Table 3: Predicting Ceremonial Bill Sponsorship

\begin{tabular}{|c|c|c|c|c|c|c|}
\hline & Model 1 & Model 2 & Model 3 & Model 4 & Model 5 & Model 6 \\
\hline Openness & $\begin{array}{l}0.121^{* *} \\
(0.049)\end{array}$ & $\begin{array}{c}0.018 \\
(0.101)\end{array}$ & $\begin{array}{l}0.066 \\
(0.075)\end{array}$ & $\begin{array}{l}0.121^{* *} \\
(0.050)\end{array}$ & $\begin{array}{c}0.026 \\
(0.102)\end{array}$ & $\begin{array}{l}0.076 \\
(0.077)\end{array}$ \\
\hline Conscientiousness & $\begin{array}{l}-0.432^{* * * *} \\
(0.044)\end{array}$ & $\begin{array}{r}-0.160^{*} \\
(0.097)\end{array}$ & $\begin{array}{l}-0.416^{* * *} \\
(0.066)\end{array}$ & $\begin{array}{c}-0.450^{* * * *} \\
(0.045)\end{array}$ & $\begin{array}{r}-0.170^{*} \\
(0.099)\end{array}$ & $\begin{array}{c}-0.428^{* * *} \\
(0.067)\end{array}$ \\
\hline Extraversion & $\begin{array}{l}0.119^{* * * *} \\
(0.041)\end{array}$ & $\begin{array}{c}0.009 \\
(0.091)\end{array}$ & $\begin{array}{c}0.060 \\
(0.065)\end{array}$ & $\begin{array}{l}0.123^{* * *} \\
(0.041)\end{array}$ & $\begin{array}{c}0.001 \\
(0.093)\end{array}$ & $\begin{array}{c}0.060 \\
(0.066)\end{array}$ \\
\hline Agreeableness & $\begin{array}{r}0.252^{* * *} \\
(0.070)\end{array}$ & $\begin{array}{l}0.218 \\
(0.150)\end{array}$ & $\begin{array}{l}0.236^{* *} \\
(0.102)\end{array}$ & $\begin{array}{c}0.273^{* * *} \\
(0.072)\end{array}$ & $\begin{array}{l}0.216 \\
(0.152)\end{array}$ & $\begin{array}{l}0.244^{* *} \\
(0.103)\end{array}$ \\
\hline Emotional Stability & $\begin{array}{c}0.081 \\
(0.065)\end{array}$ & $\begin{array}{c}0.126 \\
(0.143)\end{array}$ & $\begin{array}{l}0.170^{*} \\
(0.099)\end{array}$ & $\begin{array}{c}0.089 \\
(0.066)\end{array}$ & $\begin{array}{l}0.146 \\
(0.146)\end{array}$ & $\begin{array}{l}0.187^{*} \\
(0.101)\end{array}$ \\
\hline Distance from Floor Median & - & $\begin{array}{l}-0.054 \\
(1.090)\end{array}$ & $\begin{array}{l}-0.137 \\
(0.149)\end{array}$ & - & $\begin{array}{l}-0.125 \\
(1.098)\end{array}$ & $\begin{array}{l}-0.161 \\
(0.152)\end{array}$ \\
\hline Majority Party Status & - & $\begin{array}{c}-0.502^{* * *} \\
(0.080)\end{array}$ & $\begin{array}{l}-0.887 \\
(0.543)\end{array}$ & - & $\begin{array}{c}-0.504^{* * *} \\
(0.081)\end{array}$ & $\begin{array}{l}-0.829 \\
(0.548)\end{array}$ \\
\hline $\begin{array}{l}\text { Distance from Floor Median } \\
\times \text { Openness }\end{array}$ & - & $\begin{array}{l}0.179 \\
(0.195)\end{array}$ & - & - & $\begin{array}{l}0.170 \\
(0.198)\end{array}$ & - \\
\hline $\begin{array}{l}\text { Distance from Floor Median } \\
\times \text { Conscientiousness }\end{array}$ & - & $\begin{array}{l}-0.466^{* *} \\
(0.187)\end{array}$ & - & - & $\begin{array}{c}-0.466^{* *} \\
(0.190)\end{array}$ & - \\
\hline $\begin{array}{l}\text { Distance from Floor Median } \\
\times \text { Extraversion }\end{array}$ & - & $\begin{array}{c}0.121 \\
(0.182)\end{array}$ & - & - & $\begin{array}{l}0.140 \\
(0.185)\end{array}$ & - \\
\hline $\begin{array}{l}\text { Distance from Floor Median } \\
\times \text { Agreeableness }\end{array}$ & - & $\begin{array}{c}0.064 \\
(0.284)\end{array}$ & - & - & $\begin{array}{l}0.083 \\
(0.287)\end{array}$ & - \\
\hline $\begin{array}{l}\text { Distance from Floor Median } \\
\times \text { Emotional Stability }\end{array}$ & - & $\begin{array}{c}0.021 \\
(0.283)\end{array}$ & - & - & $\begin{array}{l}0.007 \\
(0.287)\end{array}$ & - \\
\hline $\begin{array}{l}\text { Majority Party Status } \\
\times \text { Openness }\end{array}$ & - & - & $\begin{array}{c}0.041 \\
(0.105)\end{array}$ & - & - & $\begin{array}{c}0.030 \\
(0.106)\end{array}$ \\
\hline $\begin{array}{l}\text { Majority Party Status } \\
\times \text { Conscientiousness }\end{array}$ & - & - & $\begin{array}{l}0.096 \\
(0.095)\end{array}$ & - & - & $\begin{array}{l}0.099 \\
(0.097)\end{array}$ \\
\hline $\begin{array}{l}\text { Majority Party Status } \\
\times \text { Extraversion }\end{array}$ & - & - & $\begin{array}{l}0.005 \\
(0.088)\end{array}$ & - & - & $\begin{array}{c}0.008 \\
(0.089)\end{array}$ \\
\hline $\begin{array}{l}\text { Majority Party Status } \\
\times \text { Agreeableness }\end{array}$ & - & - & $\begin{array}{c}0.041 \\
(0.148)\end{array}$ & - & - & $\begin{array}{l}0.039 \\
(0.150)\end{array}$ \\
\hline $\begin{array}{l}\text { Majority Party Status } \\
\times \text { Emotional Stability }\end{array}$ & - & - & $\begin{array}{l}-0.068 \\
(0.141)\end{array}$ & - & - & $\begin{array}{l}-0.079 \\
(0.143)\end{array}$ \\
\hline Vote Share & - & $\begin{array}{c}0.946^{* * *} \\
(0.192)\end{array}$ & $\begin{array}{r}0.948^{* * *} \\
(0.192)\end{array}$ & - & $\begin{array}{l}0.861^{* * *} \\
(0.195)\end{array}$ & $\begin{array}{l}0.864^{* * *} \\
(0.195)\end{array}$ \\
\hline Seniority & - & $\begin{array}{c}-0.040^{* * *} \\
(0.009)\end{array}$ & $\begin{array}{c}-0.040 * * * \\
(0.009)\end{array}$ & - & $\begin{array}{c}-0.038^{* * *} \\
(0.009)\end{array}$ & $\begin{array}{c}-0.039^{* * *} \\
(0.009)\end{array}$ \\
\hline Power Committee & - & $\begin{array}{l}-0.057 \\
(0.060)\end{array}$ & $\begin{array}{l}-0.052 \\
(0.060)\end{array}$ & - & $\begin{array}{l}-0.060 \\
(0.060)\end{array}$ & $\begin{array}{l}-0.054 \\
(0.060)\end{array}$ \\
\hline Chairperson & - & $\begin{array}{c}-0.534^{* * *} \\
(0.142)\end{array}$ & $\begin{array}{c}-0.526^{* * *} \\
(0.143)\end{array}$ & - & $\begin{array}{c}-0.520^{* * *} \\
(0.143)\end{array}$ & $\begin{array}{c}-0.511^{* * *} \\
(0.144)\end{array}$ \\
\hline Female & $\begin{array}{r}-0.080 \\
(0.070)\end{array}$ & $\begin{array}{c}-0.247^{* * *} \\
(0.073)\end{array}$ & $\begin{array}{c}-0.242^{* * *} \\
(0.073)\end{array}$ & $\begin{array}{l}-0.080 \\
(0.070)\end{array}$ & $\begin{array}{c}-0.247^{* * *} \\
(0.073)\end{array}$ & $\begin{array}{c}-0.242^{* * *} \\
(0.073)\end{array}$ \\
\hline Age & $\begin{array}{l}0.002 \\
(0.003)\end{array}$ & $\begin{array}{l}0.012^{* * *} \\
(0.003)\end{array}$ & $\begin{array}{c}0.012^{* * *} \\
(0.003)\end{array}$ & $\begin{array}{c}0.002 \\
(0.003)\end{array}$ & $\begin{array}{l}0.012^{* * * *} \\
(0.003)\end{array}$ & $\begin{array}{c}0.012^{* * * *} \\
(0.003)\end{array}$ \\
\hline Constant & $\begin{array}{c}-3.766^{* * *} \\
(0.294)\end{array}$ & $\begin{array}{c}-4.509^{* * *} \\
(0.590)\end{array}$ & $\begin{array}{c}-4.241^{* * *} \\
(0.431)\end{array}$ & $\begin{array}{c}-3.857^{* * *} \\
(0.305)\end{array}$ & $\begin{array}{c}-4.473^{* * *} \\
(0.597)\end{array}$ & $\begin{array}{c}-4.264^{* * *} \\
(0.437)\end{array}$ \\
\hline Cong & No & No & Yes & No & No & Yes \\
\hline AIC & 6479.694 & 6198.562 & 6205.631 & 4092.650 & 3860.240 & 3866.756 \\
\hline BIC & 6527.851 & 6312.318 & 6319.388 & 4146.722 & 3979.793 & 3986.309 \\
\hline Log Likelihood & -3231.847 & -3080.281 & -3083.816 & -2037.325 & -1910.120 & -1913.378 \\
\hline Deviance & 4098.568 & 3834.628 & 3841.697 & 4074.650 & 3820.240 & 3826.756 \\
\hline Num. obs. & 3005 & 2915 & 2915 & 3005 & 2915 & 2915 \\
\hline
\end{tabular}

N.B. Cells are logistic estimates predicting ceremonial bill sponsorship with standard errors in parentheses. Observations are at the Congress-member level. 
Table 4: Predicting Bipartisan Cosponsorship

\begin{tabular}{|c|c|c|c|c|c|c|}
\hline & \multicolumn{3}{|c|}{ Cosponsorship Rate } & \multicolumn{3}{|c|}{ Number of Bills } \\
\hline Openness & $\begin{array}{c}0.004 \\
(0.006)\end{array}$ & $\begin{array}{c}0.025 \\
(0.032)\end{array}$ & $\begin{array}{c}0.034 \\
(0.032)\end{array}$ & $\begin{array}{l}0.003 \\
(0.004)\end{array}$ & $\begin{array}{c}0.010 \\
(0.021)\end{array}$ & $\begin{array}{c}0.014 \\
(0.021)\end{array}$ \\
\hline Conscientiousness & $\begin{array}{c}-0.021^{* * *} \\
(0.005)\end{array}$ & $\begin{array}{l}0.107^{* * * *} \\
(0.030)\end{array}$ & $\begin{array}{c}0.036 \\
(0.030)\end{array}$ & $\begin{array}{c}-0.010^{* * * *} \\
(0.004)\end{array}$ & $\begin{array}{l}0.051^{\text {** }} \\
(0.020)\end{array}$ & $\begin{array}{c}0.019 \\
(0.020)\end{array}$ \\
\hline Extra & $\begin{array}{c}-0.070^{* * * *} \\
(0.005)\end{array}$ & $\begin{array}{c}-0.201^{* * *} \\
(0.027)\end{array}$ & $\begin{array}{c}-0.203^{* * *} \\
(0.027)\end{array}$ & $\begin{array}{c}-0.031^{* * *} \\
(0.003)\end{array}$ & $\begin{array}{c}-0.065^{* * *} \\
(0.018)\end{array}$ & $\begin{array}{c}-0.068^{* * * *} \\
(0.018)\end{array}$ \\
\hline Agrec & $\begin{array}{l}0.030 * * * \\
(0.009)\end{array}$ & $\begin{array}{r}-0.1 \\
(0.0\end{array}$ & $\begin{array}{l}-0.045 \\
(0.046)\end{array}$ & $\begin{array}{l}0.013^{* *} \\
(0.006)\end{array}$ & $\begin{array}{c}-0.069^{* *} \\
(0.031)\end{array}$ & $\begin{array}{l}-0.036 \\
(0.031)\end{array}$ \\
\hline Emo & $\begin{array}{c}-0.068^{* * *} \\
(0.008)\end{array}$ & $\begin{array}{r}-0.2 \\
(0.0\end{array}$ & $\begin{array}{r}-0.28 \\
(0.0\end{array}$ & $\begin{array}{c}-0.031^{* * * *} \\
(0.005)\end{array}$ & $\begin{array}{c}-0.088^{* * *} \\
(0.029)\end{array}$ & $\begin{array}{c}-0.108^{* * *} \\
(0.029)\end{array}$ \\
\hline Dist & - & $\begin{array}{r}-4.4 \\
(0.2\end{array}$ & $\begin{array}{r}-4.5 \\
(0.2\end{array}$ & - & $\begin{array}{c}-1.899^{* * * *} \\
(0.190)\end{array}$ & $\begin{array}{r}-1.9 \\
(0.1\end{array}$ \\
\hline $\begin{array}{l}\text { Distri } \\
\times\end{array}$ & - & $\begin{array}{l}-0 . \\
0.0\end{array}$ & $\begin{array}{l}-0 . \\
0.0\end{array}$ & - & $\begin{array}{c}0.002 \\
(0.037)\end{array}$ & \\
\hline $\begin{array}{l}\text { Distri } \\
\times\end{array}$ & - & $\begin{array}{r}-0.2 \\
(0.0\end{array}$ & $\begin{array}{r}-0.1 \\
(0.0\end{array}$ & - & $\begin{array}{c}-0.127^{* * * *} \\
(0.034)\end{array}$ & $\begin{array}{r}-0.075^{* *} \\
(0.034)\end{array}$ \\
\hline $\begin{array}{r}\text { Distri } \\
\times \mathrm{I}\end{array}$ & - & $\begin{array}{l}0.25 \\
(0.0\end{array}$ & & - & & \\
\hline $\begin{array}{c}\text { Distri } \\
\times\end{array}$ & - & $\begin{array}{l}0.271^{* * *} \\
(0.077)\end{array}$ & $\begin{array}{l}0.16 \\
(0.0\end{array}$ & - & & \\
\hline $\begin{array}{r}\text { Distri } \\
\times \mathrm{H}\end{array}$ & - & $\begin{array}{l}0.31 \\
0.6\end{array}$ & $\begin{array}{l}0.39 \\
(0.0\end{array}$ & - & & $\begin{array}{l}0.147^{* * * *} \\
(0.051)\end{array}$ \\
\hline Female & $\begin{array}{c}-0.259^{* * *} \\
(0.007)\end{array}$ & $\begin{array}{c}-0.166^{* * *} \\
(0.008)\end{array}$ & $\begin{array}{c}-0.172^{* * *} \\
(0.008)\end{array}$ & $\begin{array}{c}-0.123^{* * *} \\
(0.005)\end{array}$ & $\begin{array}{c}-0.078^{* * * *} \\
(0.005)\end{array}$ & $\begin{array}{c}-0.080^{* * * *} \\
(0.005)\end{array}$ \\
\hline $\operatorname{Agc}$ & $\begin{array}{c}-0.004^{* * *} \\
(0.000)\end{array}$ & $\begin{array}{r}-0.00 \\
(0.0\end{array}$ & $\begin{array}{c}0.000 \\
(0.000)\end{array}$ & $\begin{array}{c}-0.002^{* * *} \\
(0.000)\end{array}$ & $\begin{array}{c}-0.001^{* * *} \\
(0.000)\end{array}$ & $\begin{array}{l}0.000 \\
(0.000)\end{array}$ \\
\hline Con & $\begin{array}{l}0.843^{* * *} \\
(0.033)\end{array}$ & $\begin{array}{l}3.171^{* * *} \\
(0.168)\end{array}$ & $\begin{array}{l}3.204^{* * * *} \\
(0.174)\end{array}$ & $\begin{array}{c}-0.307^{* * *} \\
(0.022)\end{array}$ & $\begin{array}{l}0.660^{* * * *} \\
(0.112)\end{array}$ & $\begin{array}{l}0.677^{* * * *} \\
(0.114)\end{array}$ \\
\hline Con & No & No & Yes & No & No & Yes \\
\hline AIC & 029.468 & 33781.986 & 17692 & 29927.821 & 25053.473 & 7746.757 \\
\hline BIC & 44076.324 & 3386 & $1778 c$ & 29974.678 & 25135.337 & 7834.468 \\
\hline$L($ & -22006.734 & -16 & -883 & -14955.911 & -12512.737 & -3858 \\
\hline & 29613.48 & 19500.32 & 17662 & 13260.070 & 8538.447 & 7716.757 \\
\hline Num. obs. & 2583 & 2558 & 2559 & 2584 & 2559 & 2559 \\
\hline
\end{tabular}

Two-tailed tests: ${ }^{* * * * *} p<0.01,{ }^{* * *} p<0.05, " p<0.1$

N.B. Cells in the first three models are logistic estimates predicting the rates of bipartisan cosponsorship. Cells in second three models are Poisson estimates predicting the number of bills included in bipartisan cosponsorship coalitions, with an offset of offset of one plus the logged total number of cosponsored bills. Standard errors are in parentheses. Observations are at the Congress-member level. 
Table 5: Predicting Legislative Effectiveness

\begin{tabular}{|c|c|c|c|c|c|c|}
\hline & Model 1 & Model 2 & Model 3 & Model 4 & Model 5 & Model 6 \\
\hline Openness & $\begin{array}{l}0.095^{*} \\
(0.053)\end{array}$ & $\begin{array}{l}0.074 \\
(0.084)\end{array}$ & $\begin{array}{l}-0.024 \\
(0.067)\end{array}$ & $\begin{array}{c}0.066 \\
(0.050)\end{array}$ & $\begin{array}{l}0.091 \\
(0.080)\end{array}$ & $\begin{array}{l}-0.043 \\
(0.064)\end{array}$ \\
\hline Conscientiousness & $\begin{array}{l}0.345^{* * *} \\
(0.051)\end{array}$ & $\begin{array}{l}0.216^{* *} \\
(0.086)\end{array}$ & $\begin{array}{l}-0.030 \\
(0.060)\end{array}$ & $\begin{array}{l}0.192^{* * * *} \\
(0.049)\end{array}$ & $\begin{array}{l}0.192^{* *} \\
(0.081)\end{array}$ & $\begin{array}{l}-0.003 \\
(0.060)\end{array}$ \\
\hline Extraversion & $\begin{array}{c}-0.099^{* *} \\
(0.044)\end{array}$ & $\begin{array}{c}0.072 \\
(0.076)\end{array}$ & $\begin{array}{c}0.084 \\
(0.056)\end{array}$ & $\begin{array}{l}-0.018 \\
(0.043)\end{array}$ & $\begin{array}{l}0.066 \\
(0.075)\end{array}$ & $\begin{array}{l}0.038 \\
(0.055)\end{array}$ \\
\hline Agreeableness & $\begin{array}{l}-0.151^{*} \\
(0.079)\end{array}$ & $\begin{array}{l}-0.084 \\
(0.129)\end{array}$ & $\begin{array}{c}0.019 \\
(0.093)\end{array}$ & $\begin{array}{l}-0.005 \\
(0.072)\end{array}$ & $\begin{array}{l}-0.047 \\
(0.121)\end{array}$ & $\begin{array}{c}0.028 \\
(0.088)\end{array}$ \\
\hline Emotional Stability & $\begin{array}{l}0.364^{* * *} \\
(0.071)\end{array}$ & $\begin{array}{l}0.295^{* *} \\
(0.116)\end{array}$ & $\begin{array}{l}0.003 \\
(0.087)\end{array}$ & $\begin{array}{l}0.203^{* * *} \\
(0.066)\end{array}$ & $\begin{array}{l}0.186^{*} \\
(0.110)\end{array}$ & $\begin{array}{l}-0.041 \\
(0.082)\end{array}$ \\
\hline Distance from Floor Median & - & $\begin{array}{l}1.804^{*} \\
(0.980)\end{array}$ & $\begin{array}{c}-0.465^{* * *} \\
(0.139)\end{array}$ & - & $\begin{array}{l}1.509 \\
(0.939)\end{array}$ & $\begin{array}{c}-0.478^{* * *} \\
(0.183)\end{array}$ \\
\hline Majority Party Status & - & $\begin{array}{l}0.780 * * * \\
(0.070)\end{array}$ & $\begin{array}{l}-0.567 \\
(0.470)\end{array}$ & - & $\begin{array}{l}0.715^{* * *} \\
(0.087)\end{array}$ & $\begin{array}{c}-0.797^{*} \\
(0.442)\end{array}$ \\
\hline $\begin{array}{l}\text { Distance from Floor Median } \\
\times \text { Openness }\end{array}$ & - & $\begin{array}{l}-0.030 \\
(0.176)\end{array}$ & - & - & $\begin{array}{l}-0.112 \\
(0.167)\end{array}$ & - \\
\hline $\begin{array}{l}\text { Distance from Floor Median } \\
\times \text { Conscientiousness }\end{array}$ & - & $\begin{array}{l}-0.338^{*} \\
(0.173)\end{array}$ & - & - & $\begin{array}{c}-0.283^{*} \\
(0.165)\end{array}$ & - \\
\hline $\begin{array}{l}\text { Distance from Floor Median } \\
\times \text { Extraversion }\end{array}$ & - & $\begin{array}{l}-0.048 \\
(0.159)\end{array}$ & - & - & $\begin{array}{l}-0.028 \\
(0.156)\end{array}$ & - \\
\hline $\begin{array}{l}\text { Distance from Floor Median } \\
\quad \times \text { Agreeableness }\end{array}$ & - & $\begin{array}{c}0.136 \\
(0.259)\end{array}$ & - & - & $\begin{array}{c}0.129 \\
(0.243)\end{array}$ & - \\
\hline $\begin{array}{l}\text { Distance from Floor Median } \\
\times \text { Emotional Stability }\end{array}$ & - & $\begin{array}{l}-0.422^{*} \\
(0.243)\end{array}$ & - & - & $\begin{array}{l}-0.317 \\
(0.228)\end{array}$ & - \\
\hline $\begin{array}{l}\text { Majority Party Status } \\
\times \text { Openness }\end{array}$ & - & - & $\begin{array}{c}0.139 \\
(0.088)\end{array}$ & - & - & $\begin{array}{l}0.147^{*} \\
(0.082)\end{array}$ \\
\hline $\begin{array}{l}\text { Majority Party Status } \\
\times \text { Conscientiousness }\end{array}$ & - & - & $\begin{array}{l}0.198^{* *} \\
(0.084)\end{array}$ & - & - & $\begin{array}{l}0.141^{*} \\
(0.078)\end{array}$ \\
\hline $\begin{array}{l}\text { Majority Party Status } \\
\times \text { Extraversion }\end{array}$ & - & - & $\begin{array}{l}-0.055 \\
(0.074)\end{array}$ & - & - & $\begin{array}{l}0.026 \\
(0.071)\end{array}$ \\
\hline $\begin{array}{l}\text { Majority Party Status } \\
\times \text { Agreeableness }\end{array}$ & - & - & $\begin{array}{l}-0.081 \\
(0.129)\end{array}$ & - & - & $\begin{array}{l}-0.036 \\
(0.118)\end{array}$ \\
\hline $\begin{array}{l}\text { Majority Party Status } \\
\times \text { Emotional Stability }\end{array}$ & - & - & $\begin{array}{l}0.214^{*} \\
(0.118)\end{array}$ & - & - & $\begin{array}{c}0.174 \\
(0.109)\end{array}$ \\
\hline Vote Share & - & $\begin{array}{l}-0.015 \\
(0.173)\end{array}$ & $\begin{array}{l}-0.020 \\
(0.172)\end{array}$ & - & $\begin{array}{l}-0.070 \\
(0.180)\end{array}$ & $\begin{array}{l}-0.065 \\
(0.180)\end{array}$ \\
\hline Seniority & - & $\begin{array}{l}0.081^{* * *} \\
(0.008)\end{array}$ & $\begin{array}{l}0.083^{* * *} \\
(0.008)\end{array}$ & - & $\begin{array}{r}0.075^{* * *} \\
(0.010)\end{array}$ & $\begin{array}{l}0.076^{* * *} \\
(0.010)\end{array}$ \\
\hline Power Committee & - & $\begin{array}{c}-0.302^{* * *} \\
(0.052)\end{array}$ & $\begin{array}{c}-0.296^{* * *} \\
(0.052)\end{array}$ & - & $\begin{array}{c}-0.321^{* * *} \\
(0.066)\end{array}$ & $\begin{array}{c}-0.317^{* * *} \\
(0.066)\end{array}$ \\
\hline Chairperson & - & $\begin{array}{l}3.052^{* * *} \\
(0.114)\end{array}$ & $\begin{array}{l}2.993^{* * *} \\
(0.115)\end{array}$ & - & $\begin{array}{r}2.851^{* * *} \\
(0.113)\end{array}$ & $\begin{array}{l}2.815^{* * *} \\
(0.114)\end{array}$ \\
\hline Female & $\begin{array}{c}-0.278^{* * *} \\
(0.081)\end{array}$ & $\begin{array}{l}0.067 \\
(0.067)\end{array}$ & $\begin{array}{l}0.075 \\
(0.067)\end{array}$ & $\begin{array}{c}-0.289^{* *} \\
(0.126)\end{array}$ & $\begin{array}{c}0.042 \\
(0.098)\end{array}$ & $\begin{array}{l}0.046 \\
(0.098)\end{array}$ \\
\hline Age & $\begin{array}{l}0.030^{* * *} \\
(0.003)\end{array}$ & $\begin{array}{l}0.005^{*} \\
(0.003)\end{array}$ & $\begin{array}{l}0.005^{*} \\
(0.003)\end{array}$ & $\begin{array}{l}0.034^{* * * *} \\
(0.004)\end{array}$ & $\begin{array}{c}0.005 \\
(0.004)\end{array}$ & $\begin{array}{c}0.004 \\
(0.004)\end{array}$ \\
\hline Constant & $\begin{array}{c}-2.352^{* * *} \\
(0.325)\end{array}$ & $\begin{array}{c}-1.899^{* * *} \\
(0.498)\end{array}$ & $\begin{array}{l}-0.191 \\
(0.388)\end{array}$ & $\begin{array}{c}-2.252^{* * *} \\
(0.337)\end{array}$ & $\begin{array}{c}-1.457^{* * *} \\
(0.503)\end{array}$ & $\begin{array}{c}0.243 \\
(0.405)\end{array}$ \\
\hline Member RE? & No & No & No & Yes & Yes & Yes \\
\hline $\mathrm{R}^{2}$ & 0.087 & 0.433 & 0.435 & - & - & - \\
\hline Num. obs. & 3040 & 2943 & 2943 & 3040 & 2943 & 2943 \\
\hline AIC & - & - & - & 10390.647 & 8984.316 & 8980.358 \\
\hline BIC & - & - & - & 10450.843 & 9110.047 & 9106.089 \\
\hline Log Likelihood & - & - & - & -5185.323 & -4471.158 & -4469.179 \\
\hline Deviance & - & -65 & - & 10370.647 & 8942.316 & 8938.358 \\
\hline
\end{tabular}

Two-tailed tests: $p<0.01, " p<0.05, " p<0.1$

N.B. Cells are OLS estimates predicting legislative effectiveness with standard errors in parentheses. Observations are at the Congress-member level. 
Table 6: Predicting Number of Abstentions by Congress

\begin{tabular}{|c|c|c|c|c|c|c|}
\hline & \multicolumn{3}{|c|}{ Number of Absences } & \multicolumn{3}{|c|}{ Absence Rate } \\
\hline Openness & $\begin{array}{l}0.039^{* * * *} \\
(0.005)\end{array}$ & $\begin{array}{c}-0.168^{* * *} \\
(0.013)\end{array}$ & $\begin{array}{c}-0.274^{* * *} \\
(0.022)\end{array}$ & $\begin{array}{l}0.041^{* * * *} \\
(0.005)\end{array}$ & $\begin{array}{c}-0.178^{* * *} \\
(0.014)\end{array}$ & $\begin{array}{c}-0.293^{* * *} \\
(0.023)\end{array}$ \\
\hline Conscientiousness & $\begin{array}{c}-0.134^{* * *} \\
(0.004)\end{array}$ & $\begin{array}{c}-0.083^{* * * *} \\
(0.013)\end{array}$ & $\begin{array}{c}-0.199^{* * * *} \\
(0.020)\end{array}$ & $\begin{array}{c}-0.140^{* * * *} \\
(0.005)\end{array}$ & $\begin{array}{c}-0.087^{* * *} \\
(0.013)\end{array}$ & $\begin{array}{c}-0.230^{\text {**** }} \\
(0.021)\end{array}$ \\
\hline Extraversion & $\begin{array}{c}-0.117^{* * *} \\
(0.004)\end{array}$ & $\begin{array}{l}-0.132^{* * *} \\
(0.012)\end{array}$ & $\begin{array}{c}-0.120^{* * * *} \\
(0.019)\end{array}$ & $\begin{array}{c}-0.123^{* * * *} \\
(0.004)\end{array}$ & $\begin{array}{c}-0.137^{* * *} \\
(0.013)\end{array}$ & $\begin{array}{c}-0.138^{* * *} \\
(0.020)\end{array}$ \\
\hline Agreeableness & $\begin{array}{l}0.172^{* * *} \\
(0.007)\end{array}$ & $\begin{array}{l}0.245^{* * * *} \\
(0.020)\end{array}$ & $\begin{array}{l}0.351^{* * * *} \\
(0.030)\end{array}$ & $\begin{array}{l}0.181^{* * *} \\
(0.007)\end{array}$ & $\begin{array}{l}0.257^{* * *} \\
(0.021)\end{array}$ & $\begin{array}{l}0.389^{* * *} \\
(0.031)\end{array}$ \\
\hline Emotional Stability & $\begin{array}{c}-0.184^{* * *} \\
(0.006)\end{array}$ & $\begin{array}{c}-0.338^{* * * *} \\
(0.018)\end{array}$ & $\begin{array}{c}-0.365^{* * *} \\
(0.027)\end{array}$ & $\begin{array}{c}-0.194^{* * *} \\
(0.006)\end{array}$ & $\begin{array}{c}-0.354^{* * *} \\
(0.018)\end{array}$ & $\begin{array}{c}-0.432^{* * *} \\
(0.028)\end{array}$ \\
\hline Extr & - & $\begin{aligned}-1 . \\
0 .\end{aligned}$ & $\begin{array}{r}-2.0 \\
(0.3\end{array}$ & - & 2) & $\begin{aligned}-2 . & \\
(0 . & \end{aligned}$ \\
\hline $\begin{array}{l}\text { Extrer } \\
\times(\end{array}$ & - & & $\begin{array}{l}0.74 \\
0.0\end{array}$ & - & & $\begin{array}{l}0.8 \\
(0 .\end{array}$ \\
\hline m & - & $\begin{array}{c}-0.159^{* * *} \\
(0.028)\end{array}$ & $\begin{array}{l}0.24 \\
0.0\end{array}$ & - & $\begin{array}{r}-0.1 \\
(0.1\end{array}$ & $\begin{array}{l}0.282^{* * * *} \\
(0.047)\end{array}$ \\
\hline $\begin{array}{l}\text { Extremism } \\
\quad \times \text { Extraversion }\end{array}$ & - & 0.023 & $\begin{aligned}-0.16 \\
(0.0\end{aligned}$ & - & $\begin{array}{l}0.021 \\
(0.028)\end{array}$ & $\begin{array}{c}-0.179^{* * *} \\
(0.044)\end{array}$ \\
\hline $\begin{array}{l}\text { Extremism } \\
\quad \times \text { Agreeableness }\end{array}$ & - & $\begin{aligned} &-0.1 \\
&(0.1\end{aligned}$ & $\begin{array}{c}-0.577^{* * * *} \\
(0.069)\end{array}$ & - & $\begin{array}{c}-0.146 * * * \\
(0.047)\end{array}$ & $\begin{array}{c}-0.631 \text { *** } \\
(0.072)\end{array}$ \\
\hline $\begin{array}{l}\text { Extremism } \\
\quad \times \text { Emotional Stability }\end{array}$ & - & $\begin{aligned}-0 . \\
(0 .\end{aligned}$ & $\begin{array}{r}-0.5 \\
(0.6\end{array}$ & - & $\begin{array}{r}-0 . \\
0\end{array}$ & $\begin{array}{c}-0.601^{* * *} \\
(0.065)\end{array}$ \\
\hline Female & $\begin{array}{l}0.064^{* * *} \\
(0.007)\end{array}$ & $\begin{array}{l}0.04 \\
0.6\end{array}$ & $\begin{array}{l}0.073 \\
(0.068)\end{array}$ & $\begin{array}{l}0.067^{* * *} \\
(0.007)\end{array}$ & $\begin{array}{l}0.047^{* * *} \\
(0.007)\end{array}$ & $\begin{array}{l}0.071 \\
(0.073)\end{array}$ \\
\hline $\mathrm{Ag}$ & $\begin{array}{l}0.017^{* * * *} \\
(0.000)\end{array}$ & $\begin{array}{l}0.017^{* * * *} \\
(0.000)\end{array}$ & $\begin{array}{l}0.028^{* * * *} \\
(0.003)\end{array}$ & $\begin{array}{l}0.018^{* * * *} \\
(0.000)\end{array}$ & $\begin{array}{l}0.017^{* * * *} \\
(0.000)\end{array}$ & $\begin{array}{l}0.029^{* * * *} \\
(0.003)\end{array}$ \\
\hline Con & $\begin{array}{c}-3.455^{* * *} \\
(0.029)\end{array}$ & $\begin{array}{c}-2.822^{* * * *} \\
(0.075)\end{array}$ & $\begin{array}{c}-3.218^{* * *} \\
(0.238)\end{array}$ & $\begin{array}{c}-3.421^{* * * *} \\
(0.030)\end{array}$ & $\begin{array}{c}-2.760^{* * * *} \\
(0.077)\end{array}$ & $\begin{array}{c}-2.962^{* * *} \\
(0.250)\end{array}$ \\
\hline & No & No & Yes & No & No & Yes \\
\hline & No & No & $\mathrm{Ye}$ & No & & Yes \\
\hline $\mathrm{M}$ & No & $\mathbb{N}$ & $\mathrm{Y}$ & No & No & Yes \\
\hline & 2028.823 & 15003 & 47394 & 164890.101 & 162798.765 & 54189 \\
\hline & 2076.996 & 15011 & 4749 & 16493 & & 5429 \\
\hline & -76006.412 & -75003.568 & -23680 & -82437.051 & -81385.382 & -27077.693 \\
\hline & 135777.095 & 133771.408 & 47360 & 148778.085 & 146674.748 & 54155.38 \\
\hline & 3046 & 3046 & 3046 & 3046 & 3046 & 3046 \\
\hline
\end{tabular}

N.B. Cells in Models 1 through 3 are Poisson estimates predicting the number of absences by Congressmember pair, with an offset of offset of one plus the logged total number of votes per Congress. Cells in Models 4 through 6 are binomial logistic estimates predicting the absence rate across roll calls. Standard errors are in parentheses. Observations are at the Congress-member level. 
Table 7: Predicting DW-NOMINATE with the Big Five

\begin{tabular}{lc}
\hline \hline Intercept & $0.15^{*}$ \\
& $(0.07)$ \\
Openness & $-0.12^{* * *}$ \\
& $(0.01)$ \\
Conscientiousness & $0.13^{* * *}$ \\
& $(0.01)$ \\
Extraversion & $-0.06^{* * *}$ \\
& $(0.01)$ \\
Agreeableness & $-0.09^{* * *}$ \\
& $(0.02)$ \\
Emotional Stability & $0.14^{* * *}$ \\
& $(0.02)$ \\
\hline $\mathrm{R}^{2}$ & 0.05 \\
Adj. $\mathrm{R}^{2}$ & 0.04 \\
Num. obs. & 4780 \\
\hline Two-tailed tests: ${ }^{* * * *} p<0.001,{ }^{* * *} p<0.01, " p<0.05$
\end{tabular}

N.B. Results are OLS estimates regressing DW-NOMINATE score on the DYNAPER scores. Standard errors are in parentheses. 